\title{
History of the Juliusruh ionospheric observatory on Rügen
}

\author{
J. Weiß \\ Leibniz-Institute of Atmospheric Physics e.V., University Rostock, Field Station Juliusruh, \\ 18556 Altenkirchen, Germany \\ Correspondence to: J. Weiß (weiss.wiek@arcor.de)
}

Received: 30 August 2015 - Revised: 6 November 2015 - Accepted: 11 November 2015 - Published: 5 February 2016

\begin{abstract}
The history of the Juliusruh ionospheric observatory on Rügen is closely connected to the history of ground-based ionospheric sounding. After a short introduction to the ionospheric research and the sounding technique, the founding of the Juliusruh station in 1954 and its development until today are described. The different methods of ground-based sounding - as far as they apply to Juliusruh - are briefly discussed. The condition of life and work in a small team on the island of Rügen, remote from the respective parent institute, is also the subject of this article, whose author headed Juliusruh Station from 1965 to 2004.
\end{abstract}

\section{Introduction}

The discovery of the ionosphere goes back to the year 1839, when the German mathematician and physicist Carl Friedrich Gauss postulated that an electrically conducting region of the atmosphere could account for observed variations of the Earth's magnetic field (Gauss, 1839). At the beginning of the 20th century, long-distance radio communication became important. In 1901 Guglielmo Marconi performed the first transatlantic radio connection between Cornwall and Newfoundland. As radio waves in the atmosphere propagate along straight lines, to reach Newfoundland, the signal would have to bounce off a reflector in the higher atmosphere - the ionosphere. The ionosphere owes its existence primarily to radiation from the Sun. The energy of that radiation dissociates the electrical neutral atoms and molecules to electrically charged particles (ions and electrons). As the mass of electrons is small in comparison to that of ions, they interact with electromagnetic waves stronger than the ions. That is why the electron density $\left(N_{\mathrm{e}}\right)$ in the ionosphere is an essential factor in ionospheric radio research (Rawer, 1953).

The decrease in solar radiation in a path through the Earth's atmosphere to the ground as well as variations of density and constitution of the air along this way cause the emergence of maxima and minima in the vertical $N_{\mathrm{e}}$ profile of the ionosphere shown in Fig. 1. The regions around near the den- sity maxima, starting at the bottom, were labelled D Region, E Region and F Region (Fig. 1).

In addition to the regular flux of solar radiation, numerous other factors affect the structure and dynamics of the ionosphere. Among these factors are the geomagnetic field, the interplanetary magnetic field and the interplanetary flux of particles. Particulary the solar wind and its correlation with the 11-year cycle of solar activity together with flares of particles and $\mathrm{X}$-rays occurring in active regions around sunspots affect the Earth's ionosphere (Taubenheim, 1957). Such events are termed ionospheric disturbances. Ionospheric disturbances are very important both for practical use of the ionosphere as a mirror of radio waves and the scientific research of the Earth's upper atmosphere.

The classical method of ground-based observations of the ionosphere relies on the interaction between electromagnetic waves and the electrically charged particles in the ionosphere.

If a radio wave propagates in the ionosphere, its energy will be partly absorbed along its path. The amount of absorption is directly related to the electron density $N_{\mathrm{e}}$ along a particular path through the ionosphere.

If a radio wave with frequency $f$ propagates vertically upward in the ionosphere encountering increasing $N_{\mathrm{e}}$, it will be reflected at the height where $N_{\mathrm{e}}$ satisfies the relation

$$
f=8.98[\mathrm{~Hz}] \cdot \sqrt{N_{\mathrm{e}}\left[\mathrm{m}^{-3}\right]}
$$




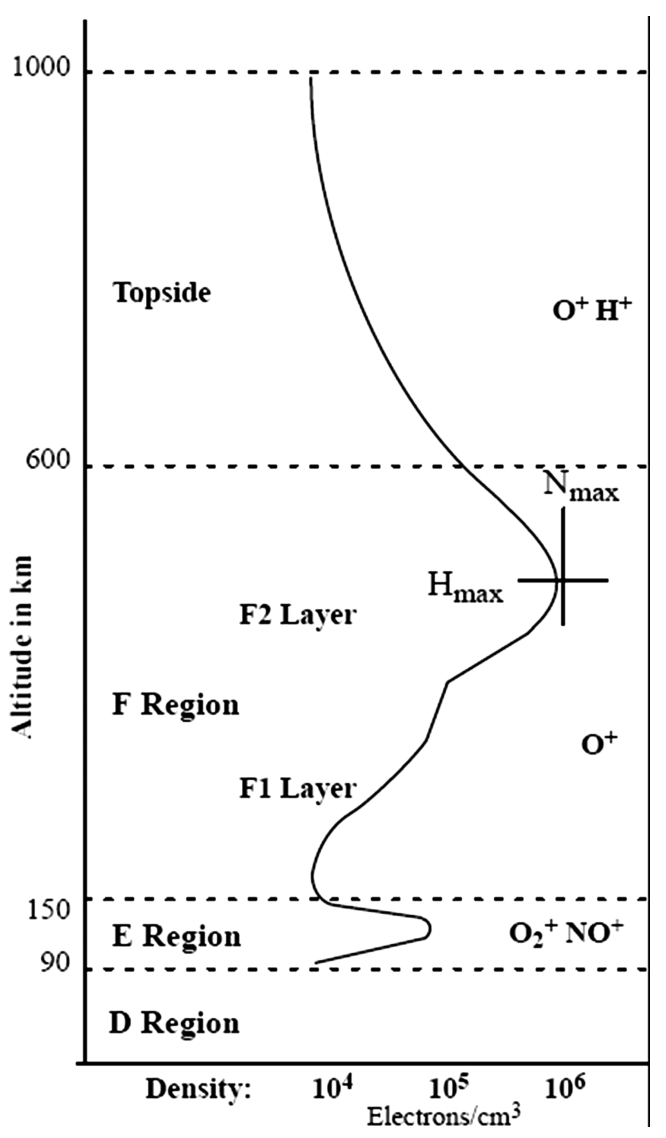

Figure 1. Vertical daytime profile of electron density.

(total refection) (Rawer and Suchy, 1967). In the D Region where $N_{\mathrm{e}}$ is too small for total reflection, tiny amounts of the wave's energy may be reflected (partial reflections) .

A method of active ground-based sounding of the ionosphere was applied for the first time in the 1920s. This method uses radio waves at frequencies between 1 and $30 \mathrm{MHz}$, vertically transmitted into the ionosphere and there completely reflected back to the Earth (Breit and Tuve, 1925). With this method it is possible to calculate

- the height of the reflecting layer from the signal transit time,

- the electron density of the reflecting point from the signal carrier frequency, and

- the electron density below the reflecting layer from the signal absorption along the path (method A1).

The Juliusruh station began operation in 1954 using active sounding of the ionosphere in the described manner.

The principle of an echo sounder is applied in other measuring systems of atmospheric research too. Instead of electromagnetic pulses, laser pulses (LIDAR) and acoustic signals (SODAR) are transmitted from the ground towards the ionosphere. Both LIDAR and SODAR were temporarily operating at Juliusruh.

Unlike the active soundings, passive methods do not require pulse transmitters. They make use of continuous wave transmission from commercial radio stations by observing the sky-wave field strength (method A3). Another passive method is to record the radiation of cosmic noise and its attenuation (CNA) due to the ionosphere (method A2). Both of these methods were applied temporarily in Juliusruh.

The ionosphere is an important indicator of global environmental changes. Natural and man-made activities or events in the Earth's atmosphere may cause short-, medium-, and long-term variations in the ionosphere. Such variations are detectable in the data archives of ionospheric stations around the world (Figs. 2 and 3).

\section{The Heinrich Hertz Institute of Oscillation Research (HHI)}

The HHI was founded 1928. Its first director, Professor K. W. Wagner, was a pioneer of communications engineering. Radio-wave propagation through the ionosphere has been a research topic of the HHI, along with technological tasks in the fields of mechanical, acoustic, and electromagnetic oscillations, since its foundation. The HHI organised an expedition to Tromsö (Norway) from 1932 to 1934 in order to research radio-wave propagation inside the polar cap (Schlegel and Lühr, 2014). In 1934 the impact of a solar eclipse on the ionosphere was investigated by observing the sky waves of radio stations.

After the end of World War II the HHI was incorporated into the Deutsche Akademie der Wissenschaften zu Berlin and continued its work under the director G. Leithäuser. In the course of the division of Germany into a Soviet-ruled East and a free West, the HHI was partitioned too into an East Berlin and a West Berlin institute. The HHI in East Berlin was headed by Professor Otto Hachenberg from 1951 to 1961. He founded the field station in Juliusruh on Rügen (Fig. 4) in 1954. In subsequent years the eastern HHI was known by various names (Böhm et al., 1997):

- Heinrich-Hertz-Institut für solar-terrestrische Physik in the period July 1967 to December 1968;

- Zentralinstitut für solar-terrestrische Physik (HeinrichHertz-Institut) in the period January 1969 to April 1984;

- Heinrich-Hertz-Institut für Atmosphärenforschung und Geomagnetismus in the period May 1984 to December 1991; and

- From 1991 after dissolving the HHI (East), the department in Kühlungsborn was newly founded as the Institut für Atmosphärenphysik (IAP). Since then the Juliusruh field station has been a part of the IAP. The IAP later joined the Leibniz Research Cluster. 


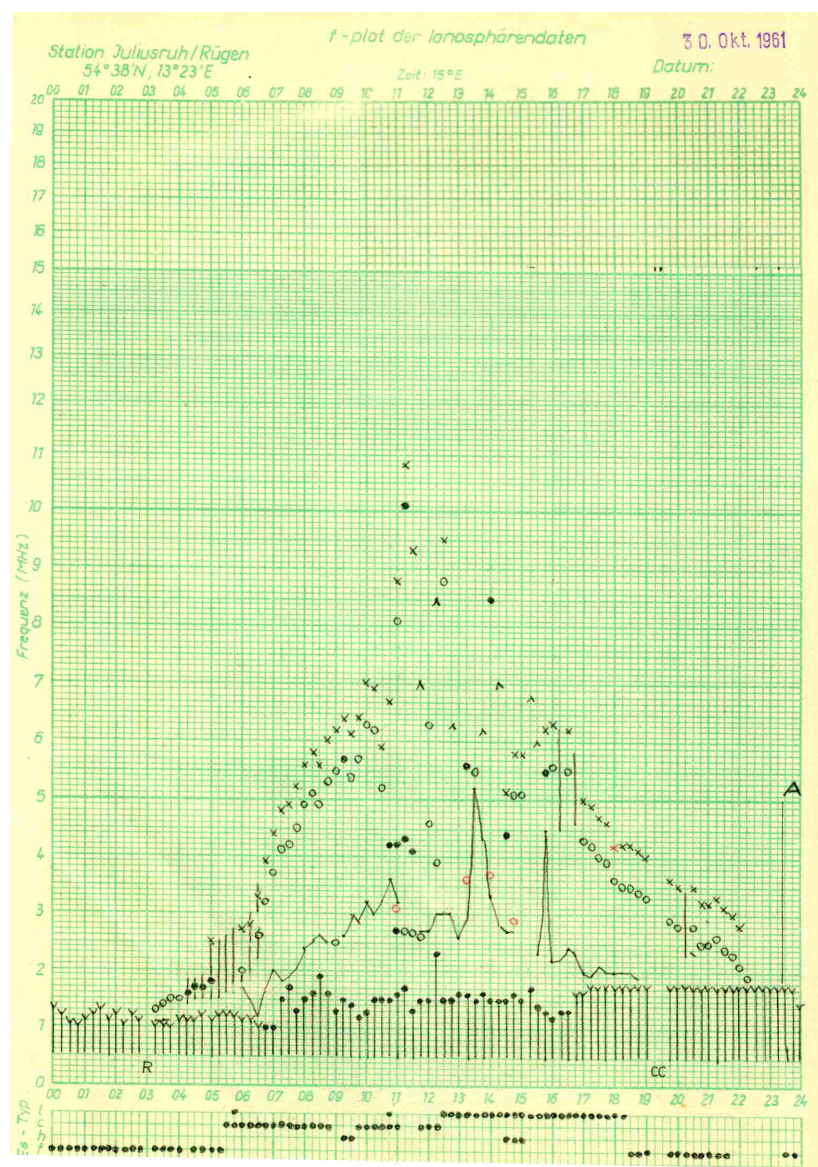

Figure 2. Original scaling results ( $f$ plots) of the Juliusruh ionosonde measurements from the day of the fission bomb test over Novaya Semlya on 30 October 1961, and from the day after (Fig. 3); 90 min after the blast, irregular variations of $F$ Region electron density commenced, lasting for nearly $5 \mathrm{~h}$.

\section{The founding of the station on Juliusruh}

On 30 June 1954 a solar eclipse occurred with the umbra trace at the southern part of Sweden and the middle Baltic. Solar eclipses act as an abrupt switch-off of the solar radiation in the umbra region. That affords an opportunity to observe the recombination process in the ionosphere.

The HHI planned an extensive measuring campaign in the vicinity of the umbra. Due to the travel restriction in East Germany, the location had to be inside the state territory of the GDR. The northernmost region of the GDR was the peninsula of Wittow on Rügen in the Baltic Sea. That location (Fig. 5) had different advantages:

- distance to the umbra region only $200 \mathrm{~km}$;

- no foreign currencies necessary;

- the operating staff did not need exit visas for "capitalist countries";

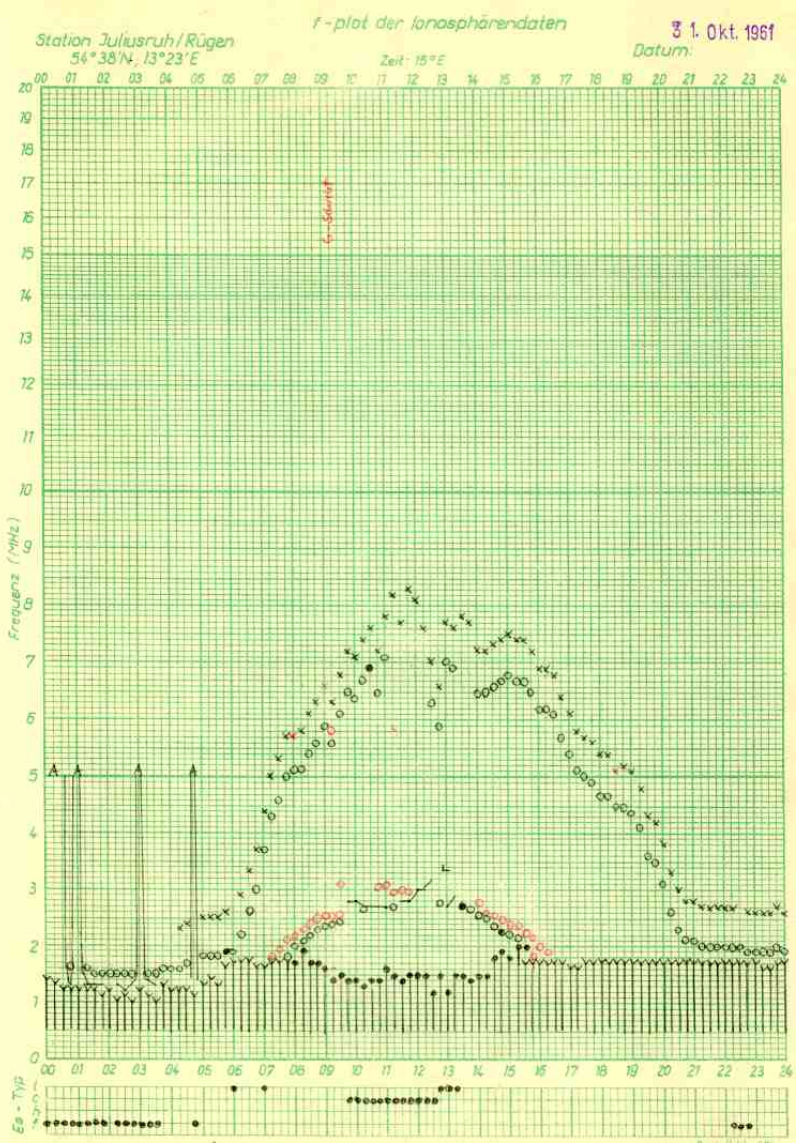

Figure 3. See caption of Fig. 2.

- the north of the seaside resort of Juliusruh was an undeveloped open woodland of sufficient size for transmitting and receiving aerials; and

- the planned field station filled a gap between the ionospheric observatories of Lindau (Germany) and Uppsala (Sweden).

For the measuring campaign the HHI constructed two wooden cottages, each $25 \mathrm{~m}^{2}$ in size, along with the necessary transmitting and receiving antennas (Figs. 7 to 10).

The wooden antenna masts had to be erected by pure manpower, because there were no truck-mounted cranes available.

In June 1954 the schedule of observations in Juliusruh started with vertical sounding in order to determine the ionospheric radio-wave absorption by method A1. For the A1 measurements a frequency of $3.86 \mathrm{MHz}$ was employed by the HHI. A second method was temporarily employed utilising a frequency that continuously rose from $1 \mathrm{MHz}$ up to $20 \mathrm{MHz}$ - the ionosonde.

Measurements employing the A1 method enabled the investigators to observe the diurnal variations as well as the seasonal variations of radio-wave absorption in the iono- 


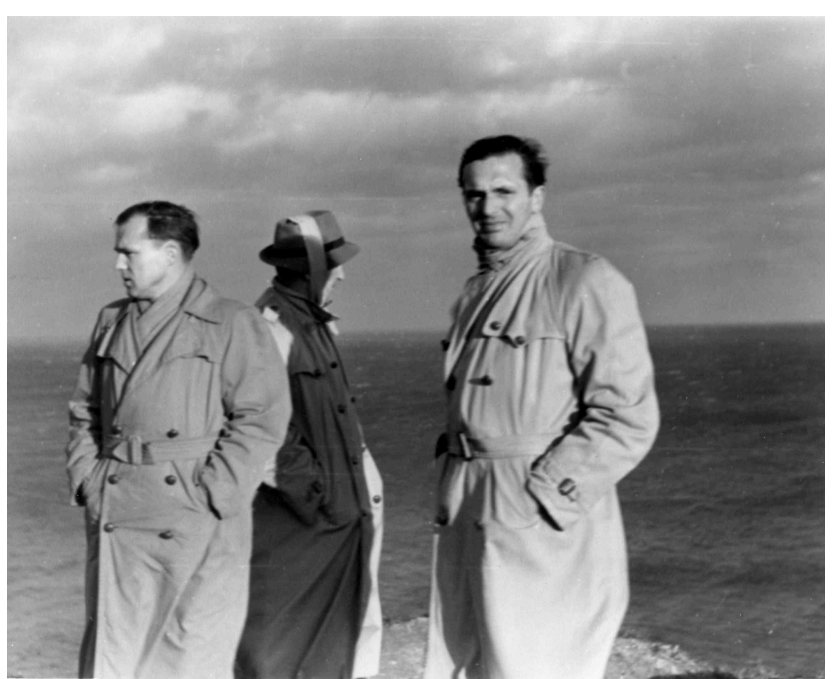

Figure 4. Professor Dr. Otto Hachenberg, director of the HHI, viewing the location for the prospective ionospheric station of Juliusruh, 1954.

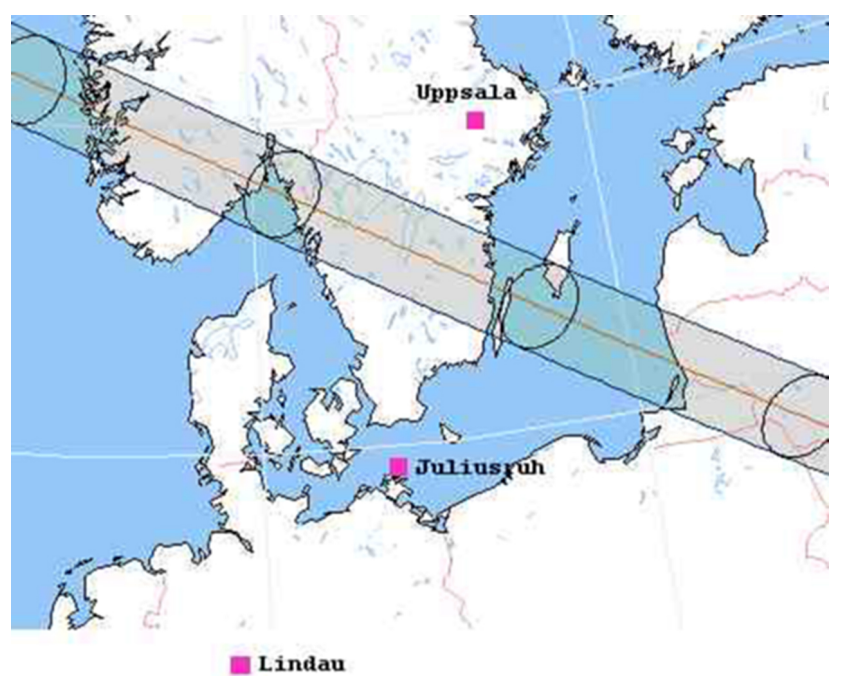

Figure 5. Path of the umbra over northern Europe during the solar eclipse on 30 June 1954.

sphere. Because this sounding system is based on the total reflection of the transmitted pulse, the carrier frequency has to be below the so-called critical frequency of the F2 layer $(f o \mathrm{~F} 2)$. The minimum value of $f o \mathrm{~F} 2$ in the undisturbed ionosphere lies below $3.5 \mathrm{MHz}$. That means that with the A1 system at $3.86 \mathrm{MHz}$, temporarily no echo is received. Therefore another A1 system at $2.055 \mathrm{MHz}$ was employed. Unfortunately, the vicinity of the coastal Rügen Radio station (ca. $10 \mathrm{~km}$ south) proved to be a disadvantage for the Juliusruh location. The broadband pulses at $2.055 \mathrm{MHz}$ interfered with the communication between Rügen Radio and the worldwide operating cargo ships, as well as the international distress frequency $2.182 \mathrm{MHz}$.

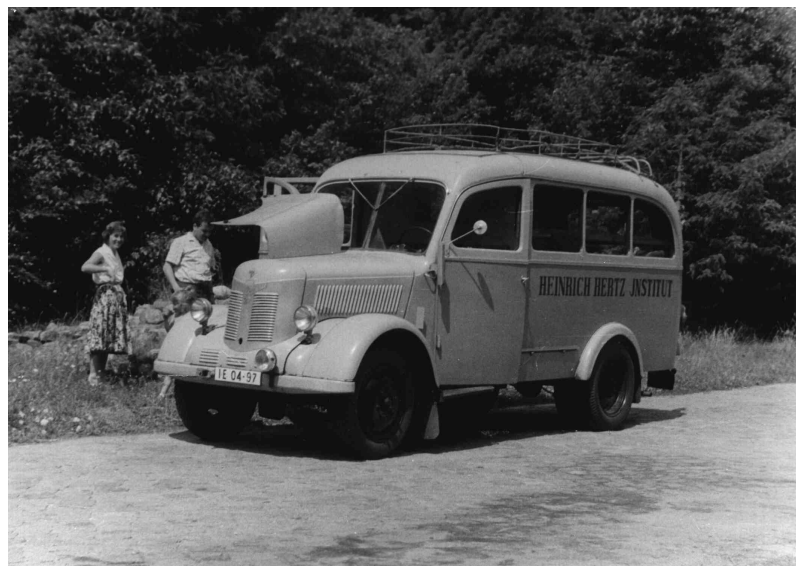

Figure 6. The staff for establishment and operation of the station travelled in turns from Berlin to Juliusruh, using the HHI's own minibus. This vehicle soon became well known on the Wittow Peninsula. Sometimes the men were accompanied by their families.

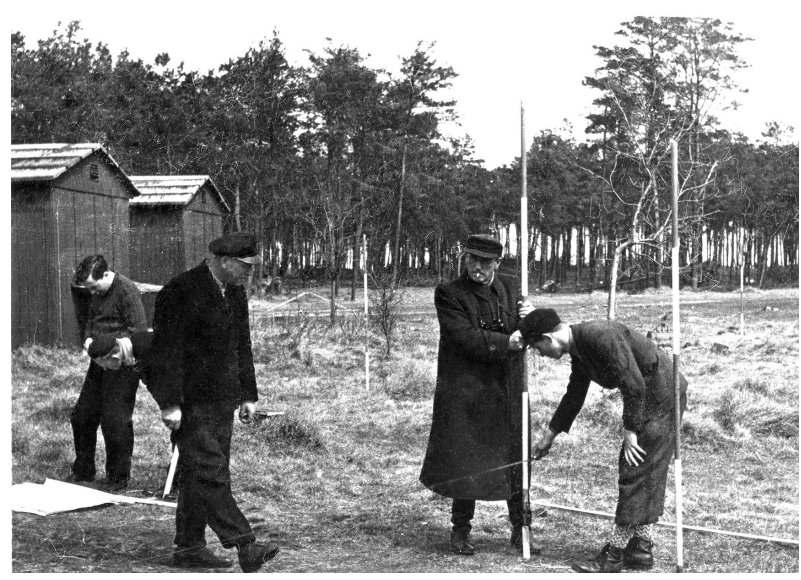

Figure 7. Surveying for the antenna farm.

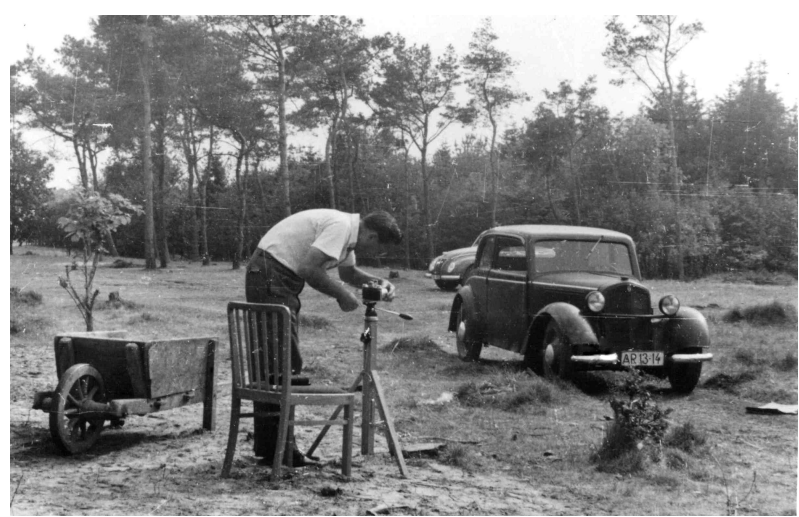

Figure 8. Surveying for the antenna farm. 


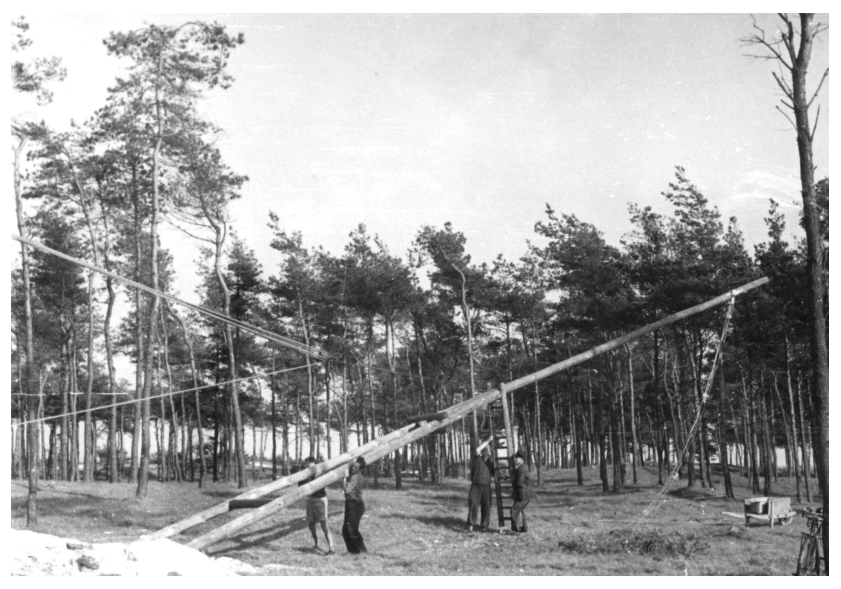

Figure 9. Erection of the first antenna masts in 1954.

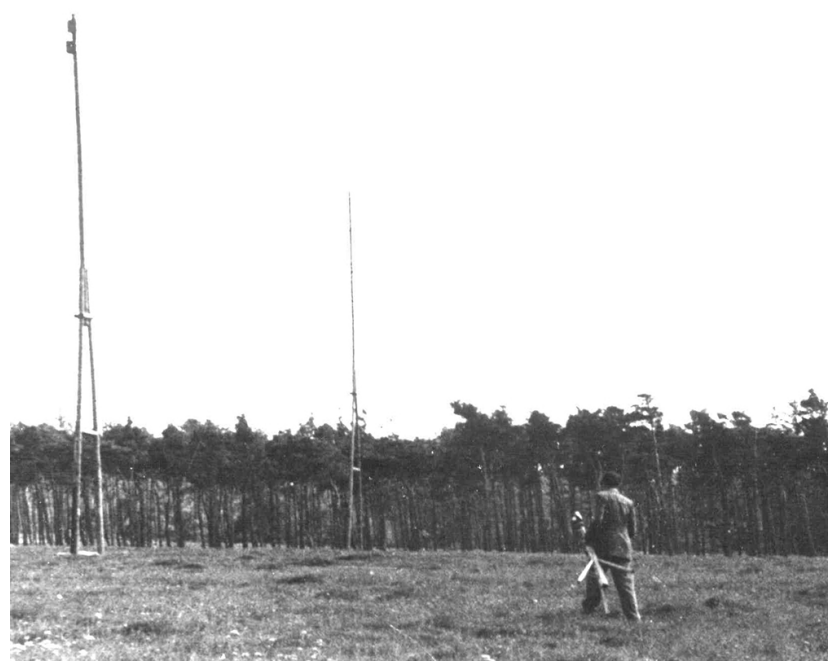

Figure 10. Erection of the first antenna masts in 1954.

During the initial operational period, the technical equipment did not enable continuous observation in Juliusruh. The reflected signals from the ionosphere were visualised by means of cathode ray tubes (A-Scopes). At that time, there was no way to record measurement data on a storage medium. Sitting at the A-Scope (Figs. 11 and 12), the operator had to read out and to notify the altitude of the reflecting layer as well as the amplitude of the reflected pulses. The schedule of A1 measurements during the solar eclipse provided the readings during periods of a few minutes with large data gaps (Fig. 13).

The ionosonde was - as previously the A1 system - constructed in the laboratories of the HHI in Berlin. Like the A1 system, the ionosonde employed pulses that are reflected in the ionosphere. The ionosonde of the HHI required, for the whole frequency range ( 1 to $20 \mathrm{MHz}$ ), a process time of $10 \mathrm{~min}$. An ionosonde scans the bottom side $N_{\mathrm{e}}$ profile up to its maximum; the result is a so-called ionogram. The iono-

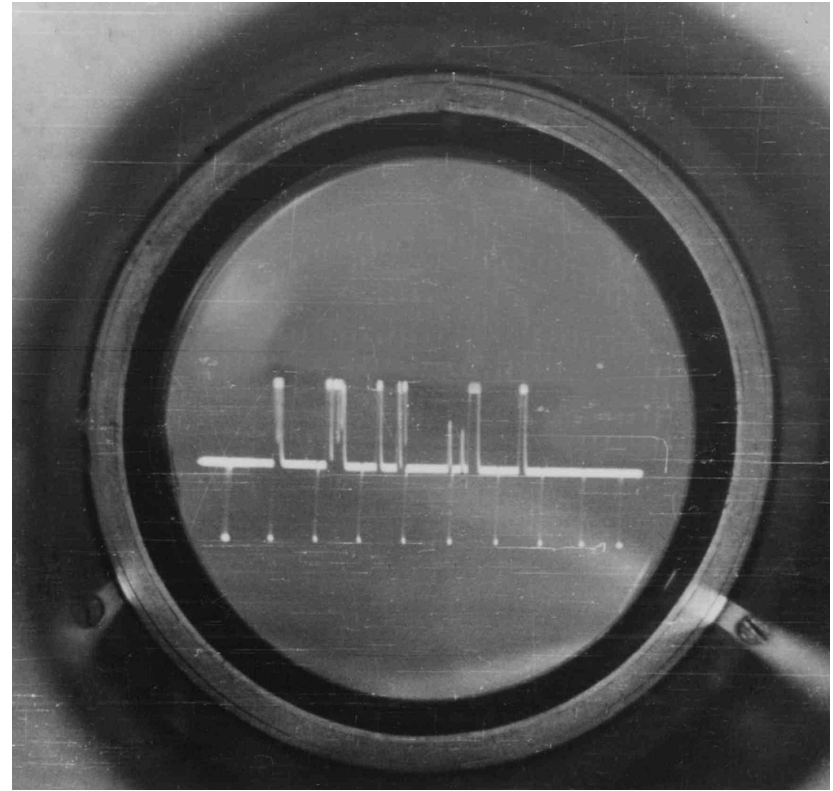

Figure 11. A-Scope with echo signals.

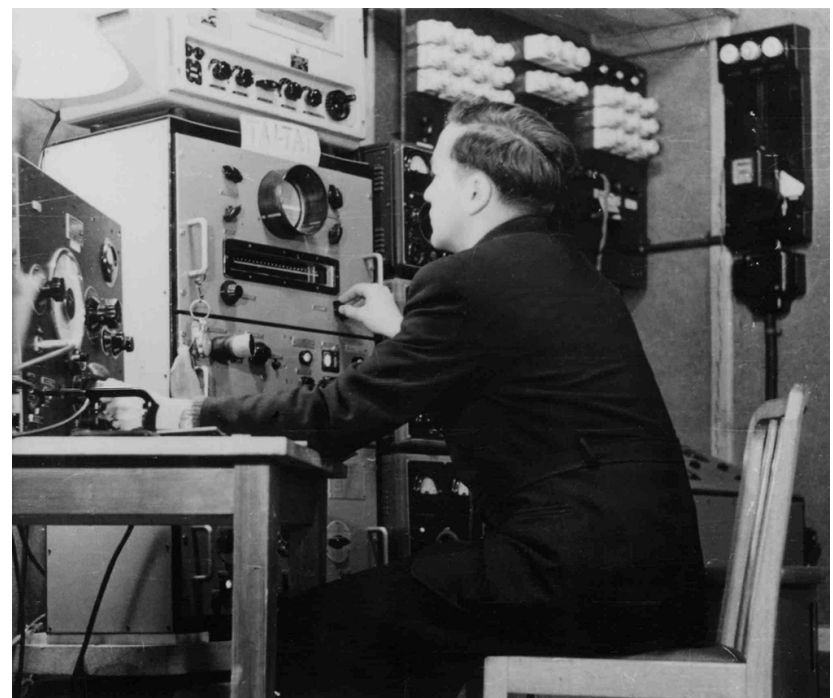

Figure 12. Operator at work.

grams of the first ionosonde in Juliusruh, however, were of poor quality due to the faint HF power of only $1.7 \mathrm{~kW}$. The antenna too was not optimal for that broad frequency range.

After the solar eclipse, operations at Juliusruh Station were continued on the experimental schedule. The laboratory staff in Berlin worked on improving the sounding systems and the Juliusruh Station served as a field test site for the improved equipment. Since the station was not permanently staffed, the country postman making his daily rounds via bicycle stopped by to check whether everything was in order.

In 1955 the HHI decided that Juliusruh Station - initially founded as a temporary field station - should be included 


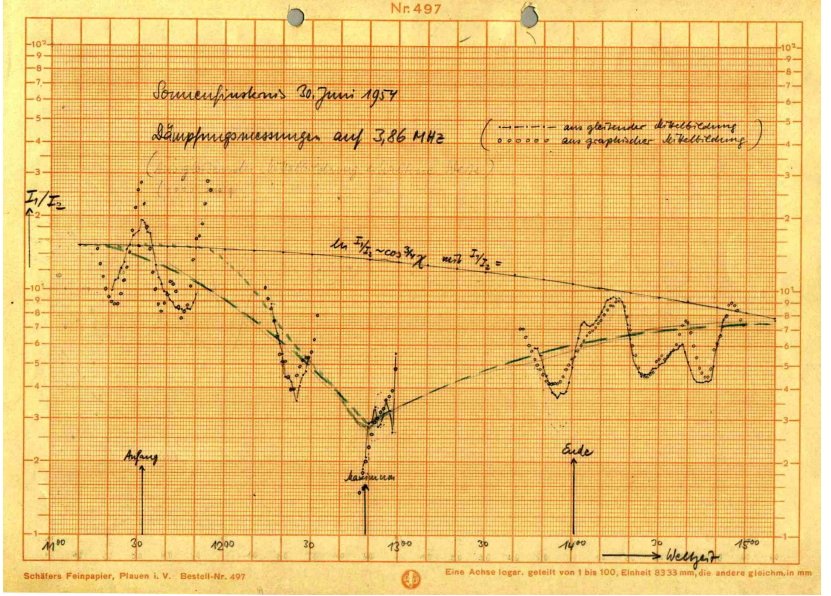

Figure 13. First results of absorption measurements with the A1 method at Juliusruh during the solar eclipse of 6 June 1954, 13:0015:00 GMT.

in the observation programme of $\mathrm{HHI}$ for the International Geophysical Year (IGY) 1957/1958. The IGY provided coordinated geophysical measurements all over the world.

The observation programme had to start on 1 July 1957 and continue for 1 year. The schedule for Juliusruh provided

- periodical soundings by ionosonde and evaluation of critical frequencies of the ionospheric $\mathrm{E}$ and $\mathrm{F}$ layers; and

- daily midday acquisition of the ionospheric absorption by vertical sounding (method A1) at fixed frequencies 2.05 and $3.86 \mathrm{MHz}$.

The implementation of this programme started at the end of 1955. It was then decided to continue the observations past the IGY and to maintain Juliusruh as a fixed ionospheric station.

In the summer of 1956, the HHI began with the construction of a solid station building. Unfortunately, the new building was not ready for the start of the IGY. The station staff had to delay moving into the new facility until November 1957 . The new building contained

- five bedrooms, one kitchen, and restrooms for the station operators and periodically visiting HHI staff;

- two office rooms;

- a photo laboratory, mechanical workshop, and electronic laboratory;

- an accumulator room, and a room for power infeed and stabilisation;

- a transmitter room in the tower section (ground floor);

- Receiver- and observation-room in the tower-section (upper floor).

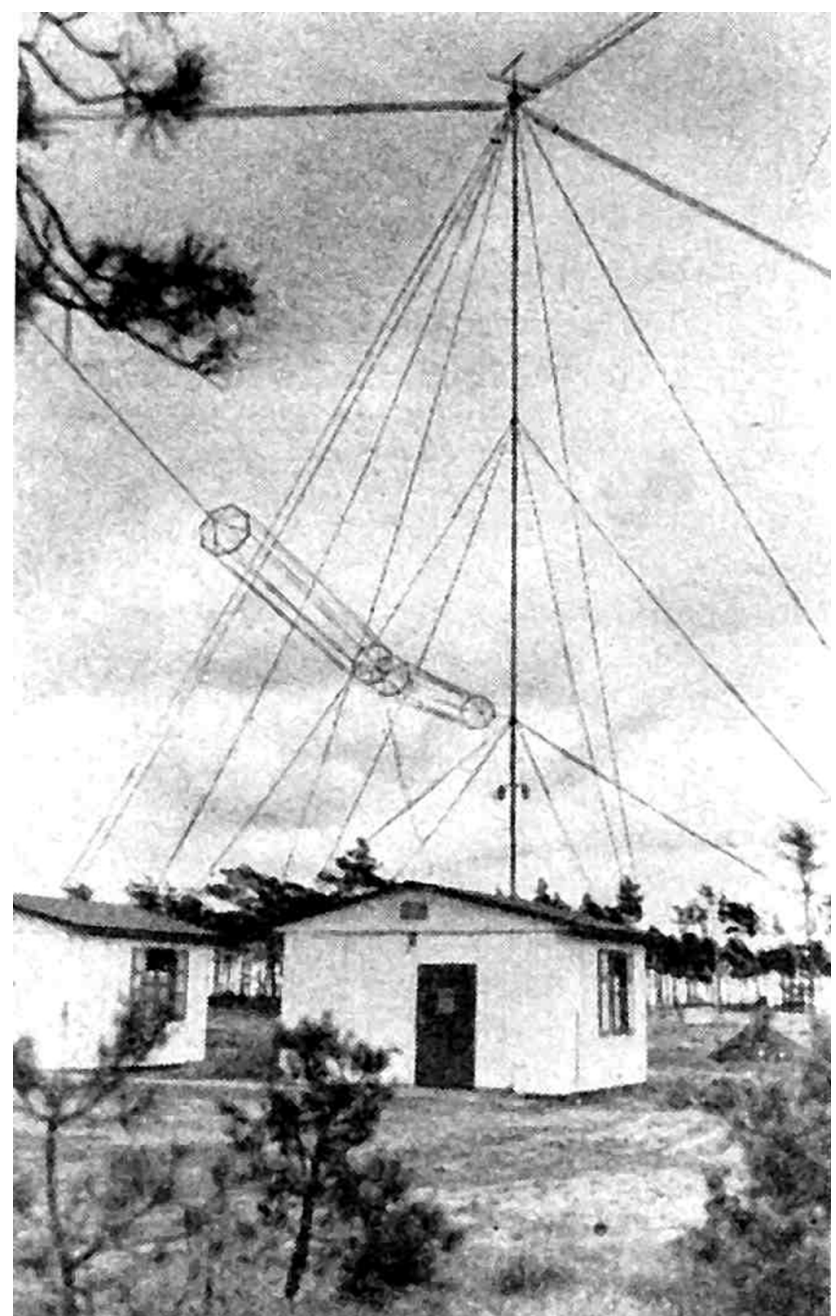

Figure 14. The transmitting and receiving antennas were renewed in 1955. Now as a central pole a $32 \mathrm{~m}$ high aluminium tube was erected. It supported the broadband delta transmitting antenna.

- one apartment for the station's manager;

- the attic, first serving as a stockroom. Later, it was partly converted into workrooms and additional bedsitting rooms; and

- rooms for heating and for drinking water supply.

In order to attenuate the excess heat, radiated by transmitters and receivers composed of hundreds of electronic tubes, a powerful ventilation/cooling system was built. All technical rooms were networked with the antenna field by cable tunnels. The substantial station building (Fig. 47) has satisfied the requirements for experimental and routine activities to the present day. When the bedrooms were no longer required, they were converted into office space.

The performance of the ionosonde was boosted by optimising the antennas and the power of the transmitter from 1.7 to $10 \mathrm{~kW}$. In the summer of 1956 the improved equip- 


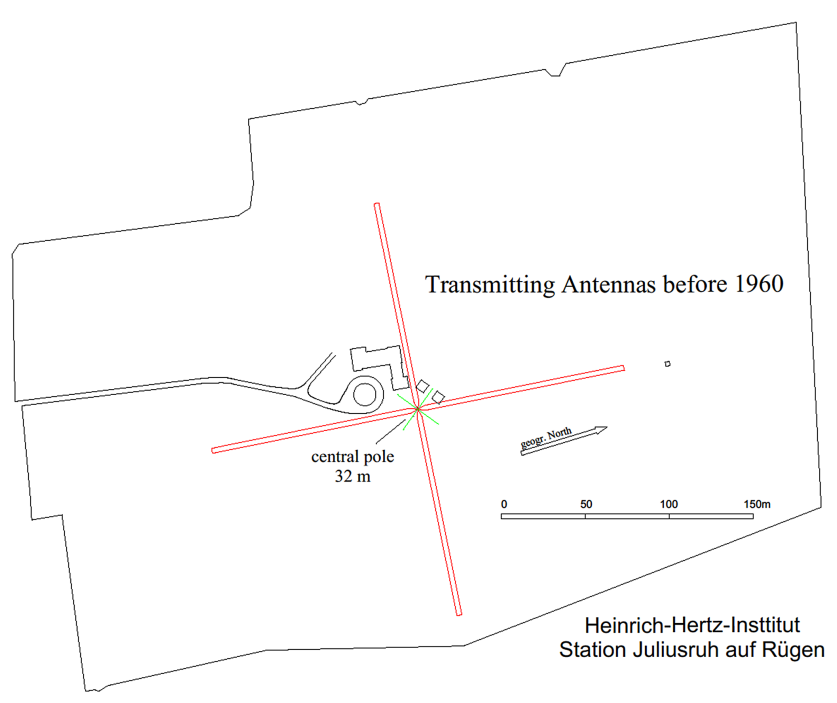

Figure 15. Grounds of the Juliusruh station with the broadband antennas. The two small squares in the middle indicate the wooden cottages from the founding year. The main building was established in 1957.

ment was tested at Juliusruh Station. Operation of the new equipment promptly sparked protests on the part of Rügen Radio. They felt disturbed by the sounding pulses (pulsewide $100 \mu \mathrm{s}$, pulse repetition rate $30 \mathrm{~Hz}$ ). This was a valid concern because the carrier frequency during one sounding scrolls through the whole spectrum of medium- and shortwave radio frequencies. In order to reduce the interference duration of an ionogram scan, the duration was changed from $10 \mathrm{~min}$ down to $25 \mathrm{~s}$. The recording of ionograms was done by a photo recorder.

For the automatic recording of echo amplitudes from A1 sounding, a photo recorder with continuous film pull movement was attached to the A-Scope, enabling continuous recording of the ionospheric absorption data. During periods when the critical frequency of the F2 layer was below $4 \mathrm{MHz}$, a second A1 sounder at $3.18 \mathrm{MHz}$ was used.

\section{Establishment of a service for warning and reporting of ionospheric disturbances}

Since 1947, one of the tasks of the HHI - besides the pure research - has been the prediction of usable frequency bands for short-wave radio transmission. This working field was of particular interest for the government bodies. There were 12 customers inside the GDR paying for this service, among them

- the state-owned commercial and fishing fleets,

- Rügen Radio coastal radio station,

- the Radio DDR International broadcast station,

- the police,

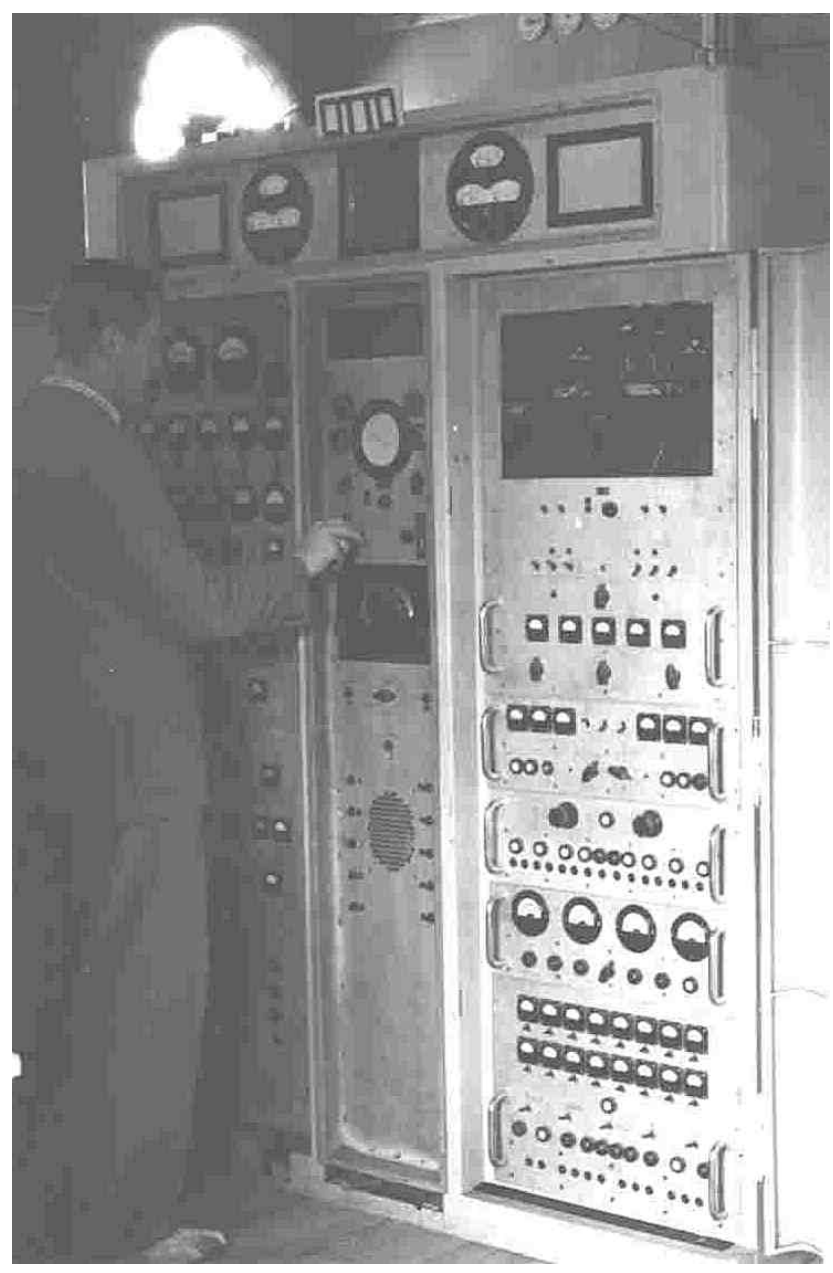

Figure 16. The ionosonde of HHI operating in Juliusruh, 1956.

- the military,

- the Ministry of State Security, and

- the diplomatic service.

The forecasts were compiled by a special procedure, developed already in World War II, one for each month (Fig. 18). The observations of ionosonde stations all over the world among them Juliusruh - were used as input for the forecast processing (Lange and Tietze, 1963). In 1956, predictions for 40 different short-wave communication lines were compiled.

In 1957, an additional service was established: the shortterm warnings, labelled by the keyword funkobs. The funkobs was used to inform the customers of forecasts about an ionospheric disturbance. If this happens, the predicted frequency band is available only to a limited extent. These warnings were issued by Juliusruh Station, and they are still a permanent task of the station.

To monitor the ionosphere with respect to irregularities, continuous observation of the geomagnetic field is essential. Electrically charged particles, moving in the Earth's upper 


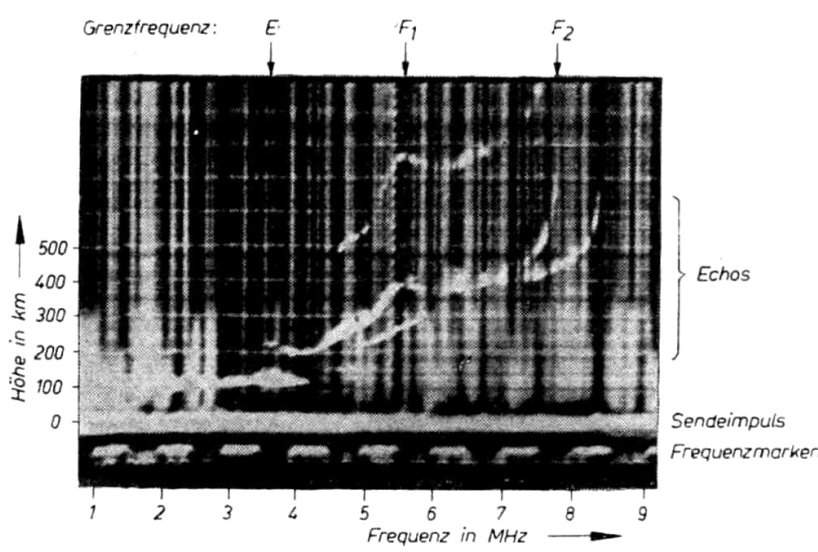

Figure 17. Ionogram at noon, Juliusruh, June 1956.

atmosphere and in the near-Earth space, generate magnetic fields, which then interfere with the permanent geomagnetic field. That causes geomagnetic variations (Fig. 19). The permanent flux of particles outgoing from the Sun, the so-called solar wind, is in interaction with the geomagnetic field. If the solar wind becomes "squally" by events on the Sun (e.g. proton flares), the geomagnetic field features typical variations. Subsequently with a time delay of 8 to $36 \mathrm{~h}$, ionospheric disturbances occur due to the precipitation of particles, an ionospheric storm.

Thus the monitoring of the geomagnetic field affords an opportunity to generate short-term predictions for radio transmission via the ionosphere. For this reason a fluxgate magnetometer (Förster Probe) was deployed at Juliusruh Station, using electronic tubes, until 1967. Subsequently a mechanic field balance system was used (Fanselau, 1962) (Fig. 20). Since 2002 a digital triaxial fluxgate magnetometer has been employed.

The Mögel-Dellinger effect (MDE) is another type of ionospheric disturbance (Traxler and Schlegel, 2014). It frequently causes, due to sudden enhancement of short-wave absorption in the lower ionosphere, a total black out of ionospheric short-wave transmissions. The origin of this effect is enhanced X-radiation, emanating from solar flares. As the Xradiation propagates with the speed of light, this effect occurs coincidentally with a discovery of the flare by optical observation. As a result, the MDE is unpredictable. The effect in the ionosphere usually decays after 10 to $20 \mathrm{~min}$.

In case of unpredictable disturbances, customers are immediately informed once the disturbances are discovered. For indication of MDE, monitoring the sky waves of shortwave radio stations is a proven method. Since 1957, the Juliusruh station has monitored radio station Radio Luxemburg at the frequency of $6 \mathrm{MHz}$ in search of MDEs. In later years, the monitoring of the A1 sounding measurements served this purpose.

In order for an ionospheric disturbance warning to be effectively relayed to interested customers in time, a staff of

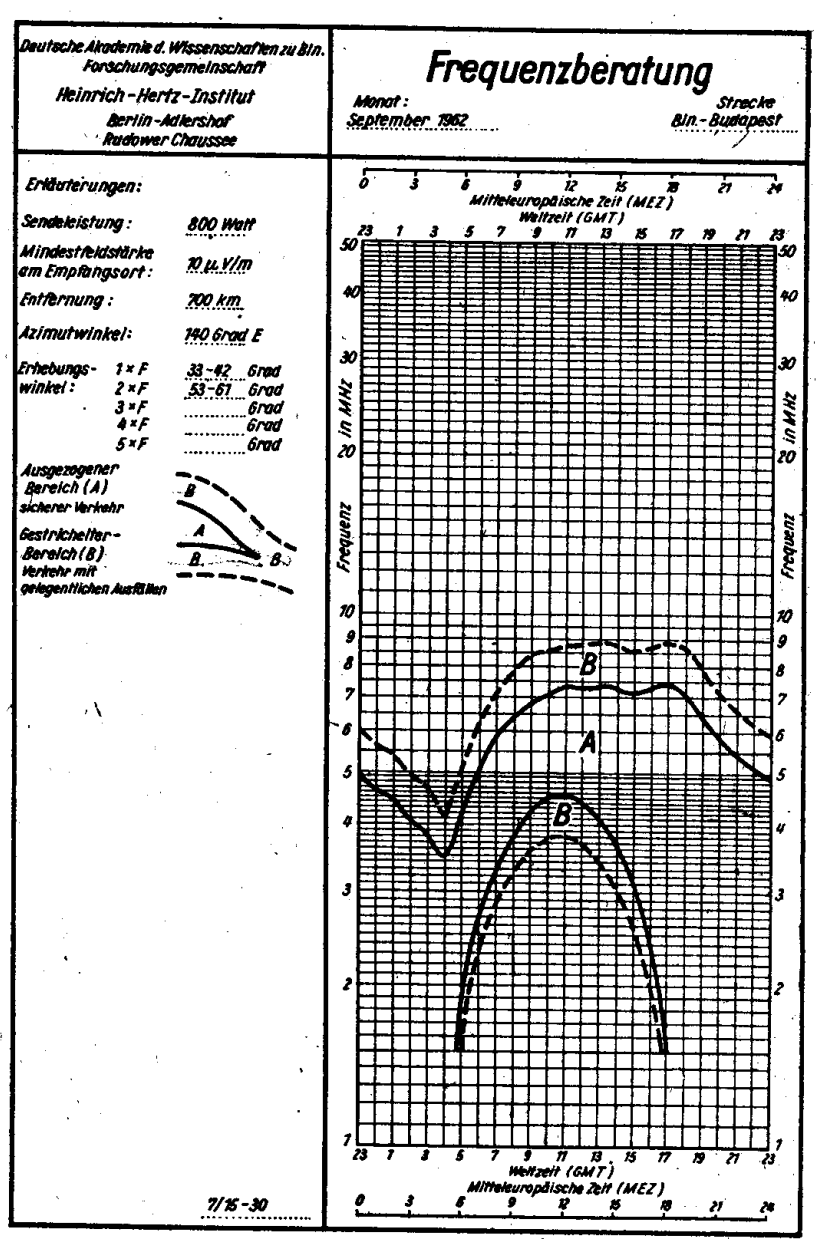

Figure 18. An example of forecast, issued by HHI, for short-wave communication between Berlin and Budapest for September 1962.

permanent operators at the station is necessary. Thus since 1958 a staff of resident employees has been tasked with continuous observations and maintenance at the station. The station was guided both by a physicist and an engineer who arrived from Berlin on a bi-weekly rotation.

\section{Station Juliusruh after the end of IGY}

After the IGY, Juliusruh had obtained the status of a master station inside the network of ionosonde stations. Thus its long-term survival was ensured. From 1959 the official name was Ionospheric Station Juliusruh, as registered in the international ionosonde network.

After the great success of the IGY (Taubenheim and Fürstenberg, 1958), the IUGG (International Union of Geodesy and Geophysics) decided on a new programme for internationally coordinated observations in the upper atmosphere, the IQSY (International Quiet Sun Year). According to this programme, in the years 1964 and 1965 - the period of expected minimum of the solar activity - intensive obser- 


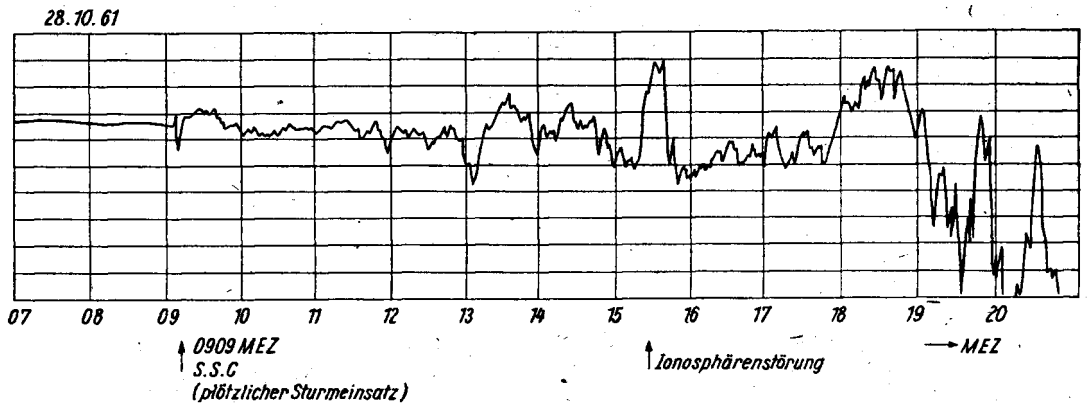

Figure 19. Sudden commencement of geomagnetic storm (SSC), followed by ionospheric storm. Juliusruh, 28 October 1962.

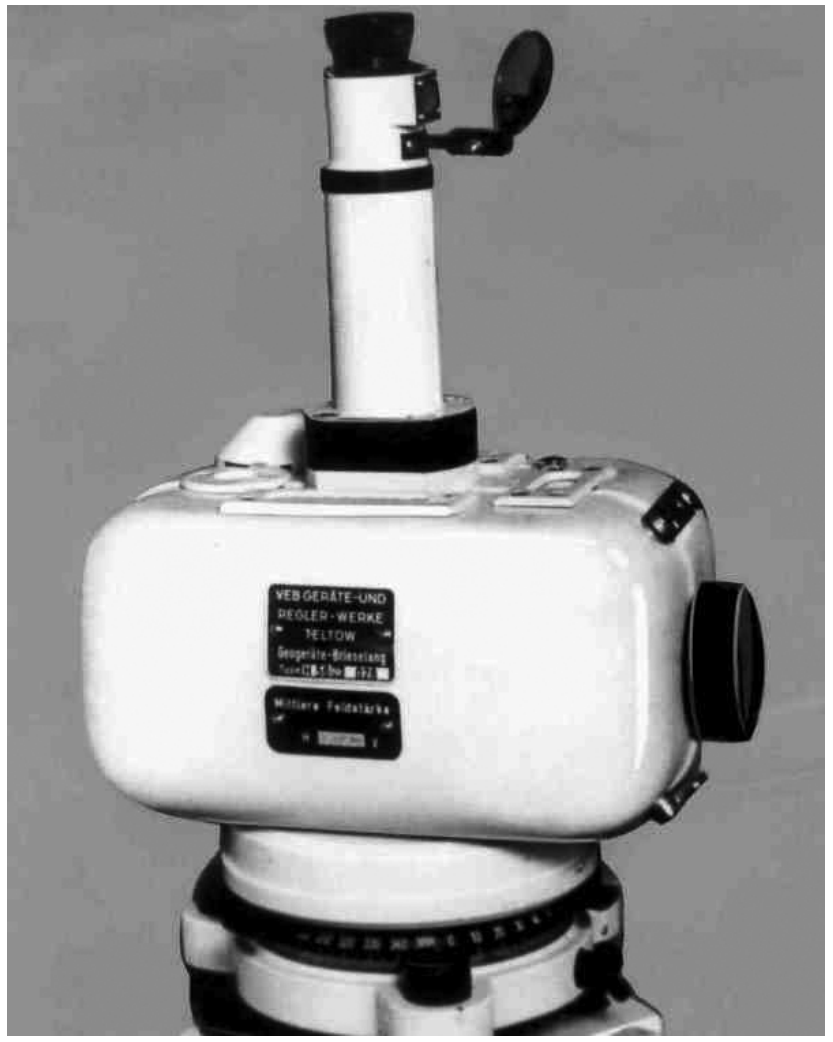

Figure 20. Field balance system, developed by Gerhard Fanselau.

vations of the ionosphere with a worldwide unified schedule were again provided.

The advances in high-frequency engineering and electronics enabled a lot of improvement in the observation technique.

Now ionograms became real-time visible by means of afterglowing screens, displaying the whole ionogram for nearly 30 s. Previously the ionograms were in full view only after the film was developed.

For A1 recording, sample-and-hold circuits were developed for fixing the peak values of received needle pulses and plotting it with an ink recorder. Previously the pulses were recorded on photographic film, requiring arduous scaling work. As the pulse peak of a few microseconds now was stretched up to minutes, the pulse repetition rate could be reduced from 30 down to $1 \mathrm{~Hz}$. In this way the continuous disturbance of Rügen Radio and other radio communication services was considerably diminished.

In 1960 the HHI began a large-scale effort to optimise the transmitting and receiving antennas of the different sounders. One free-standing central tower (1961) standing at $70 \mathrm{~m}$ and two wire-supported towers (1964) standing at $52 \mathrm{~m}$ were raised (Fig. 21). Since 1964 three nested rhombic loops have been used with a peak height of $70 \mathrm{~m}$ and a maximum horizontal extent of $220 \mathrm{~m}$ for transmitting. During the ionogram scan from 0.5 up $20 \mathrm{MHz}$, the transmitting antennas were switched (from large to short) at the frequencies 3.2 and $12 \mathrm{MHz}$. That way an acceptable resistor-matching between transmitter and antenna was achieved. The receiving antenna was a delta loop, stretched orthogonally to the transmitting antenna with a peak height of $70 \mathrm{~m}$, a base length of $220 \mathrm{~m}$ and a base height of $15 \mathrm{~m}$.

In 1965 the old ionosonde, constructed at the HHI, was replaced by a sounder of the type SP-3, which was batchproduced by the East Berlin factory Funkwerk Köpenik for the ionosonde network in the Soviet Union. The sounder had a pulse power of $50 \mathrm{~kW}$ and a frequency range from $0.5 \mathrm{up}$ to $20 \mathrm{MHz}$.

The ionograms were photographically recorded (Fig. 23). The ionograms of the day before had to be processed the next morning after film development and drying. This process, the so-called scaling of ionograms, took place by means of an enlarger. To enumerate the standard parameters of the ionogram, the scaling was done, observing the rules of the URSI (Union Radio Scientifique Internationale), listed in a special manual (Piggott and Rawer, 1961). Thus the enumerated standard parameters were comparable to results of stations all over the world, using the same rules. The scaling results were then communicated by telex in the form of a so-called URSIGRAM to the World Data Centers (WDC), where they are available to all scientists.

In 1965 the Observatorium für Ionosphärenforschung (OIF) in Kühlungsborn was incorporated into the HHI, and 


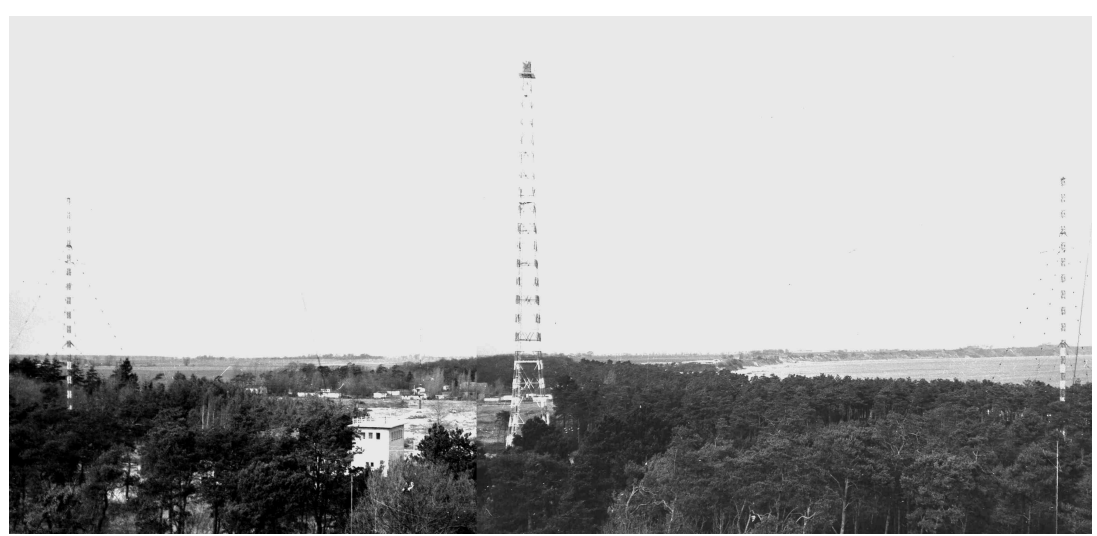

Figure 21. The towers bearing the transmitting and receiving antennas of the ionosonde, used from 1964. The freestanding central tower stands $70 \mathrm{~m}$ high, and the outer guyed towers stand $52 \mathrm{~m}$ high.

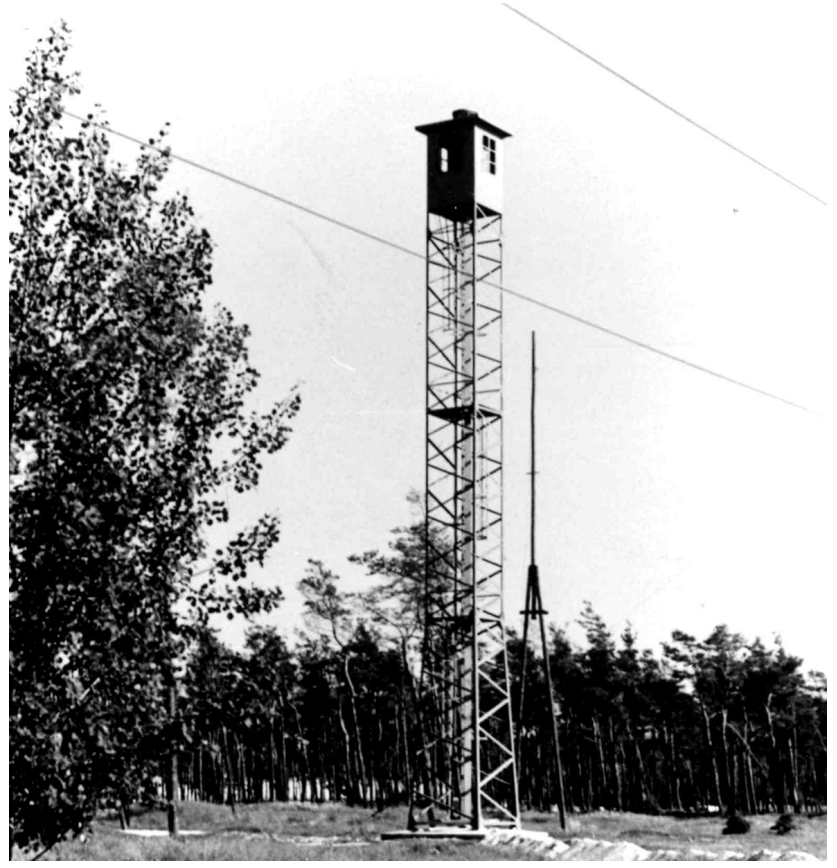

Figure 22. In 1960, for the A1 sounders at 3.18 and $3.86 \mathrm{MHz}$, a freestanding $20 \mathrm{~m}$ tower was erected. It carried four half-wave dipoles for transmitting and receiving. From 1961, the A1 sounders at both frequencies operated continuously.

the ionospheric station of Juliusruh was put under operational and administrative control of the OIF. Professor Dr. ErnstAugust Lauter, previously the director of the OIF, now became the director of the radio-wave propagation and ionosphere department of the HHI and graduated to the position of Secretary General of the Academy of Sciences of the GDR. In 1967 he became director of the HHI. The HHI now changed its name to Heinrich-Hertz-Institut für solarterrestrische Physik, and the Juliusruh station was officially renamed Ionosondenstation Juliusruh/Rügen.

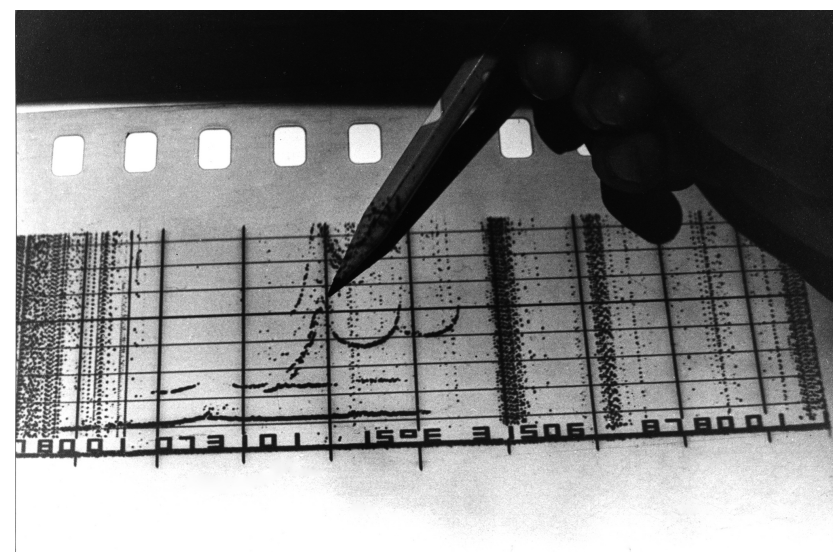

Figure 23. Ionogram processing by means of enlarger. Type of ionosonde: SP-3, Juliusruh, 1987.

From 1963 to 1974 Juliusruh Station also included a former flak tower (anti-aircraft gun tower) from World War II in the dune area $5 \mathrm{~km}$ southward. At this tower a scientist of the HHI from Berlin conducted applied research of thermal radiation of objects at sea on behalf of the East German Army. Those studies most probably served the purpose of discovering political refugees trying to leave the GDR by boat. This work was top secret, and the staff of Juliusruh Station had no clearance to access the tower until the end of the study. Later on, at the radar bogy, an airglow photometer was mounted by the scientists in Juliusruh for use in Antarctica (see Sect. 7).

Due to the tense economic situation in the GDR, it was nearly impossible to hire external contractors for the maintenance and further development of the station's equipment. Therefore, in Juliusruh, in addition to the head of the station, who resided inside the station, up to 14 staff members were employed, residing in the villages near the station. In 1965 the permanent staff of Juliusruh Station consisted of 


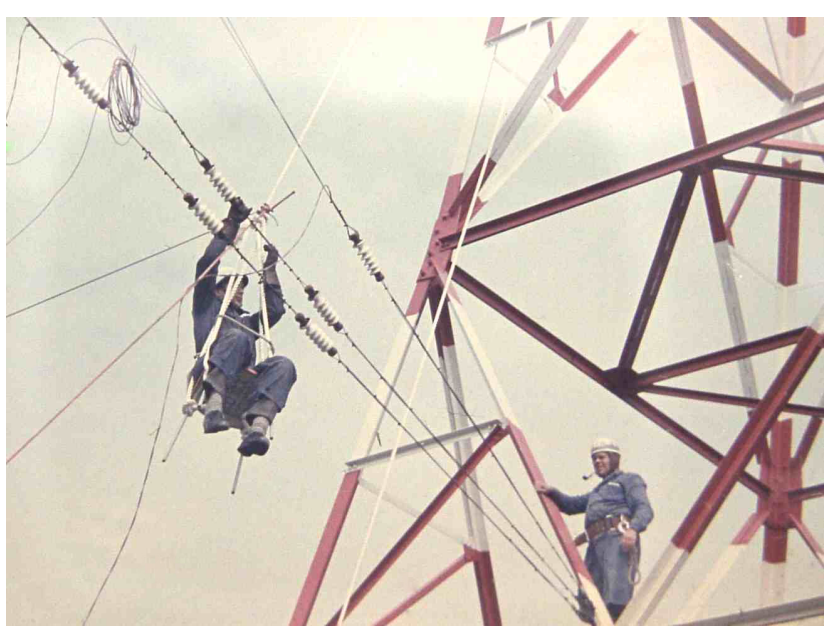

Figure 24. One of the observers (right) and the author (hanging) mounting the feeders for the ionosonde antenna (1965).

- one physicist (head of the station),

- one engineer,

- one radio technician,

- four observers, working in shifts,

- two grounds keepers,

- one metal worker and stoker,

- two house cleaners,

- one cook,

- one administrator, and

- one person for measurement data evaluation.

Additionally, up to three students, $\mathrm{PhD}$ candidates, and interns from the universities of Rostock or Greifswald were living and working in the station. Temporary personnel were dispatched from the HHI in Berlin and Kühlungsborn for the implementation of new experiments.

The power grid connection $(50 \mathrm{~Hz})$ of the village of Juliusruh before 1980 was deficient. The AC voltage sometimes was only $190 \mathrm{~V}$ instead of $220 \mathrm{~V}$. Therefore inside the station a second power grid was installed for the electronic equipment. It was stabilised by means of automatically working adjustable transformers. During the frequent gales - the Wittow Peninsula in the vernacular is called "Windland" - the local power grid often collapsed. Thus an emergency power aggregate was acquired. It was an old one, made in the UK, which had already been used for years in the Werner Seelenbinder Hall, the biggest East Berlin multipurpose hall. Unfortunately this generator equipment never ran due to the lack of spare parts. Later a new generator made in the GDR could be purchased.

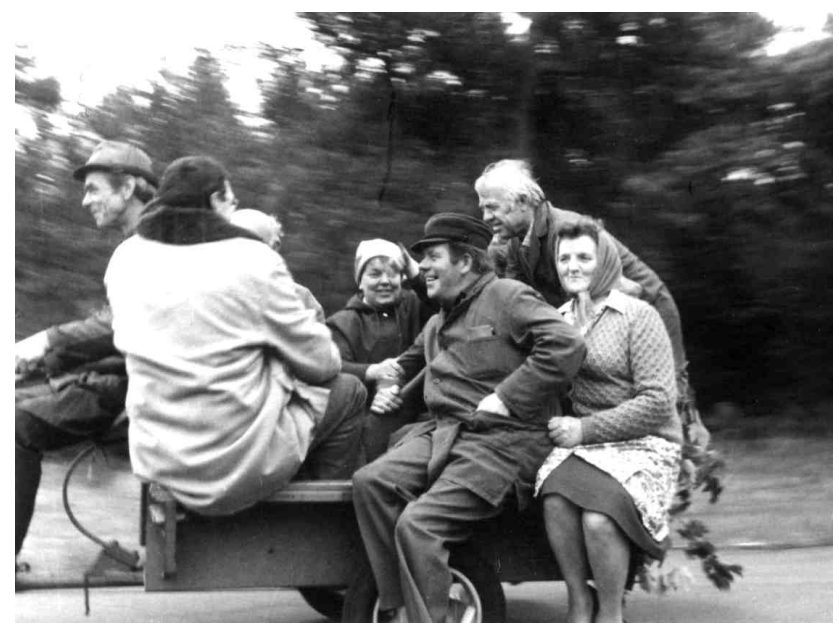

Figure 25. The "Feierabend-Brigade" of Juliusruh Station celebrates the completion of a pathway trough the compound with a celebratory drive.

The building for the power generator moonlighting was built by the "Feierabend-Brigade" of the station. The Feierabend-Brigade was a layman workers unit, consisting of nearly the whole staff of Juliusruh Station, including the author, working for money in their free time. In East Germany, professional construction companies worked preferably for military or economically important projects. As a result, the Feierabend-Brigade was a common phenomenon all over the GDR. Our Feierabend-Brigade was engaged until the eighties for different tasks, such as building reconstruction, roadway clearances and laying of cable on the property. Each end of project was heartily celebrated (Fig. 25).

International communication was seriously restricted in the GDR. The TELEX network for communication with Western countries - "capitalist countries" in official speech - was blocked, and the HHI had to obtain exceptional permission from the post ministry for the station of Juliusruh. A condition for that permission was to bar the windows on the ground floor of the station building to avoid the use of TELEX by intruders. That problem could be fixed by moving the TELEX equipment into a room on the second floor of the tower section and keeping it closed. This room was previously used as a photo laboratory each night to develop $15 \mathrm{~m}$ of ionogram film. Again, the Feierabend-Brigade was asked to convert the former TELEX room on the ground floor into a photo laboratory.

\section{Wildlife inside of the station compound}

The whole compound of the station was fenced in, and at the entrance gates visitors were warned by danger signs against high voltages and falling parts of antennas. Nevertheless, vacationers during the summertime intruded into the compound. This changed drastically when additional signs from 


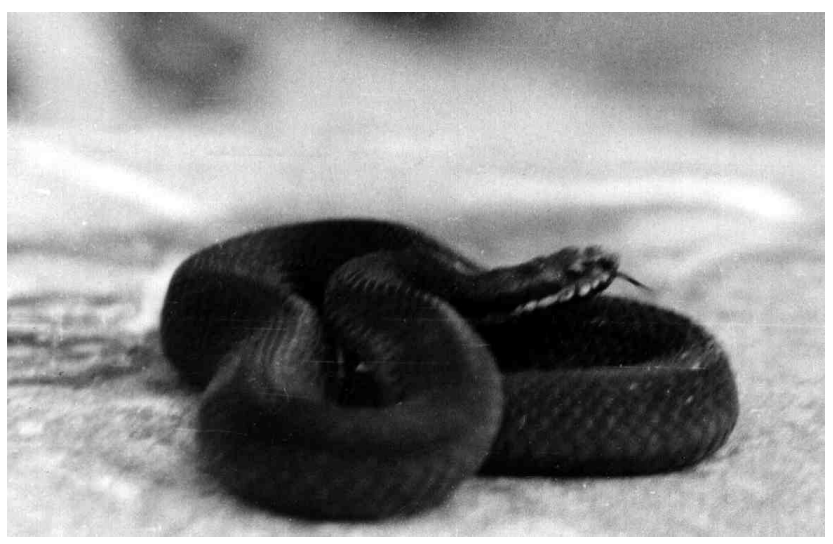

Figure 26. A black coloured adder (Hell Adder). This species lives in the compound, deterring the vacationers from intruding.

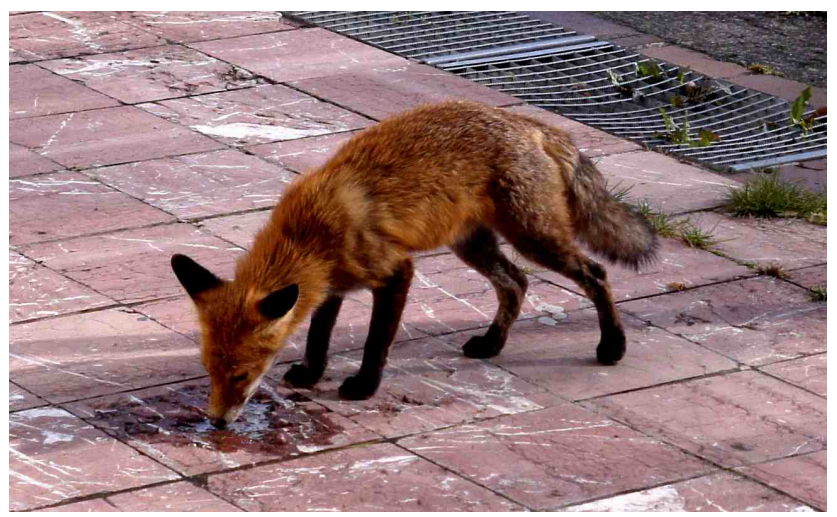

Figure 27. Wildlife inside of the sheltered station compound.

the nature conservation authority were attached, asking visitors not to harass the black adders (Fig. 26) living inside the compound.

Besides adders, several other wild animals also live inside the fenced station grounds (Figs. 27 to 30). But one ubiquitous species is strangely absent from the Wittow Peninsula: the mole. Throughout the rest of Rügen, the mole is a pest. The tour guides like to explain the absence of moles to their clients by a miracle of Saint George, whose statue is located inside the church of Wiek in Wittow. We think we have discovered the mystery by accident.

After a light Earth tremor on 5 May 1981 with the epicentre north of Rügen, the Potsdam Central Institute for Physics of the Earth intended to install a seismometer in the Juliusruh Station area, to fill a gap in the seismographical network. But test measurements showed a permanent high microseismic level all over the peninsula, obstructing useful operation of a seismic station. Thus the station with international stations code GE-LID was established in Liddow in the core of Rügen.

The cause of this microseismic activity in the Wittow Peninsula seems to be the continuous beating of sea waves

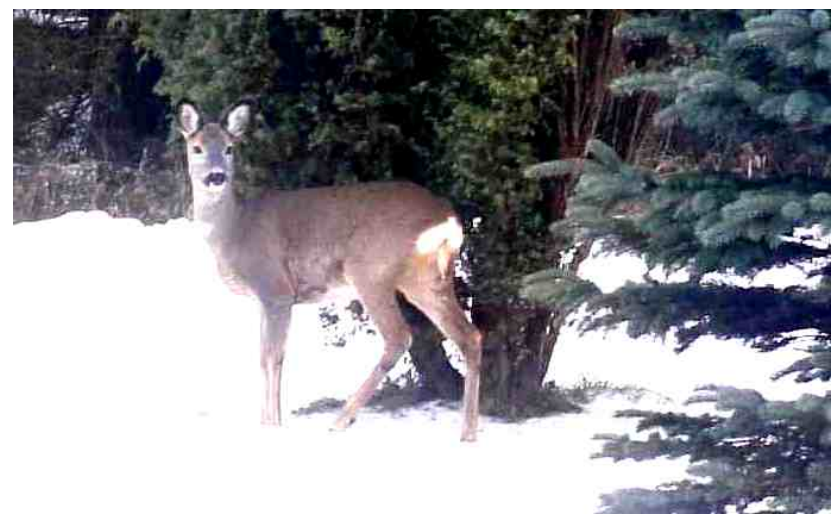

Figure 28. Wildlife inside of the sheltered station compound.

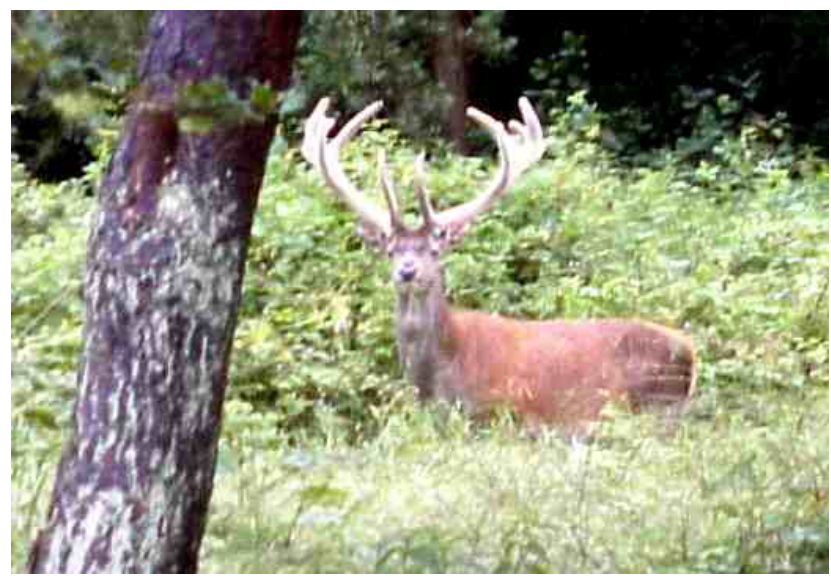

Figure 29. Wildlife inside of the sheltered station compound.

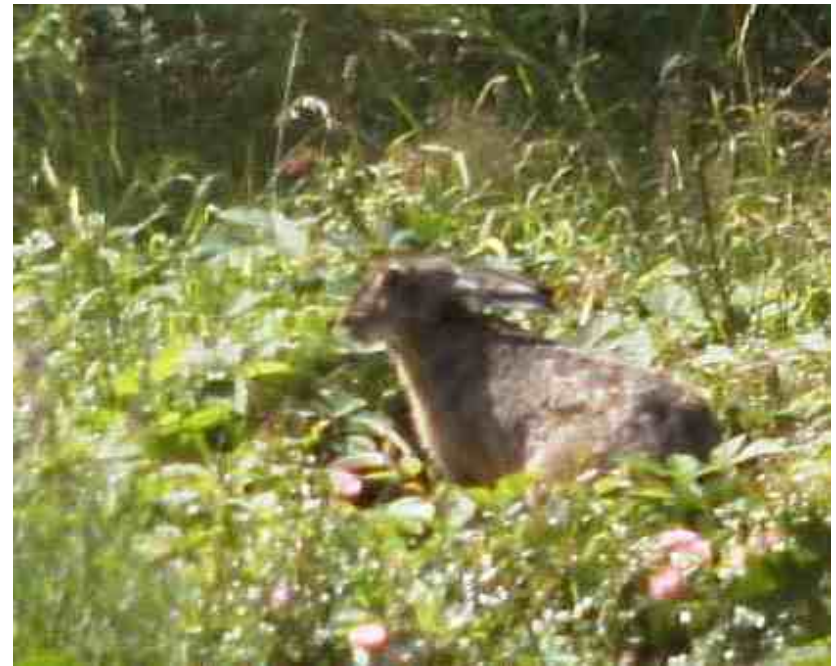

Figure 30. Wildlife inside of the sheltered station compound. 
against the shore in connection with a special tectonic structure of the subsoil.

The sensitivity of moles to special infrasonic frequencies is well known. Obviously the microseismic spectrum in Wittow contains these frequencies.

\section{Antarctic expeditions}

In 1974 and 1975 the Juliusruh station made significant contributions to the research programme and the equipment of the East German participation in the 21st, 22nd and 23rd Soviet Antarctic Expeditions (SAE). For the first time, in 1975 a German station was founded in Antarctica, initially as an outpost of the New Lazarev Soviet Antarctic station. Afterwards the German station was named Station Georg Forster. The author as the head of Juliusruh Station was assigned by the administration of the HHI to design the scientific observations and to lead the German expedition group. The state security service of the GDR blocked his participation only a few months before the start. This job then was given to physicist Dr. Hartwig Gernandt of the Lindenberg Meteorological Observatory. After his participation in the 13th Soviet Antarctic Expedition he had written his doctor dissertation at Juliusruh Station between 1969 and 1971 (Gernandt, 1971). He was familiar with the scheduled observation technique. The programme in Antarctica included vertical ionospheric sounding and airglow measurements, using equipment from Juliusruh.

The Soviet station at ca. $2 \mathrm{~km}$ distance provided the meals and medical assistance for the German group. The Germans had to support themselves with other needs, like lodging, power, and radio communication with home. The logistical arrangements in the GDR were made by the National Committee of Geodesy and Geophysics (NKGG) of the Academy of Science. Several 20' containers were purchased for lodging, laboratory and power supply. Moreover, two crawler tractors were acquired for trekking the containers over the shelf ice (Fig. 31). As a joke, the German expedition participants named the tractors "Ernst August" and "Bodo" after the two protagonists Ernst August Lauter (director of HHI) and Bodo Tripphahn (NKGG).

Some of the containers were completely equipped in Juliusruh Station. The blacksmith in a nearby village had constructed heavy iron sledges for crossing the Antarctic ice shelf while moving equipment. The antenna with a wiresupported mast of $30 \mathrm{~m}$ was erected and tested in the compound of Juliusruh Station. The expedition participants were trained here on the equipment before the expedition began.

Between 1975 and 1979 staff members of Juliusruh overwintered in Antarctica repeatedly. The embarkment started in October 1975 in Leningrad on the Kapitan Markov icebreaking freighter. The A1 sounder, already installed readyto-operate in Juliusruh in one of the containers, was located on the deck of Kapitan Markov and used for ionospheric ab-

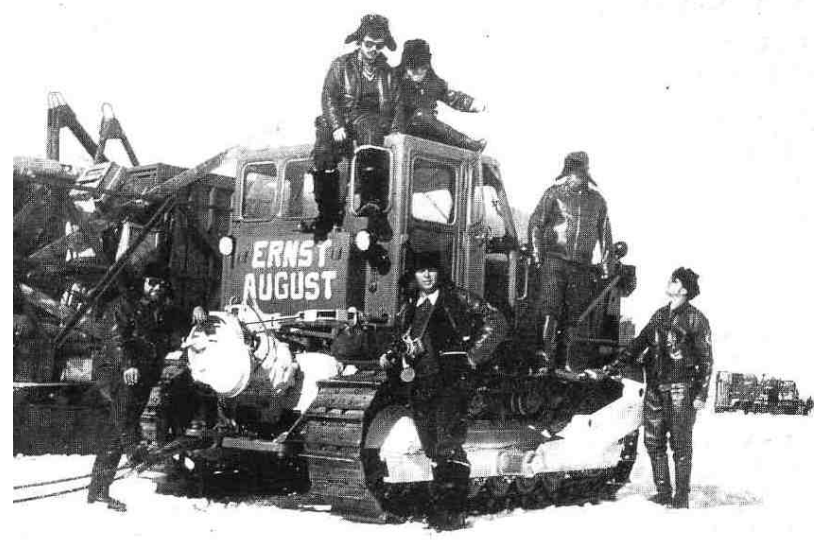

Figure 31. Unloading upon the Antarctic ice shelf.

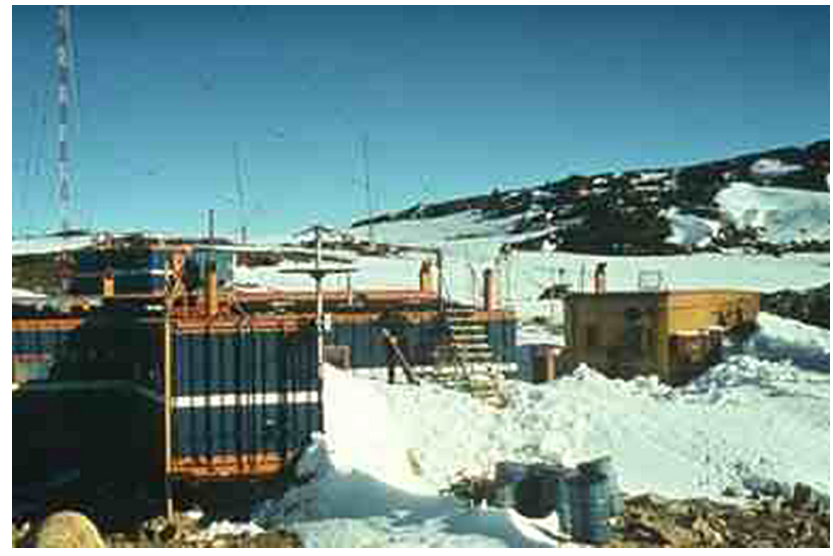

Figure 32. German station near New Lazarew.

sorption measurement during the passage to Antarctica, to get a meridional profile. In March 1976 the cargo was unloaded from the ship onto the ice shelf, and from that point the cargo had to be transported on ice $90 \mathrm{~km}$ to the Schirrmacher Oasis in the south-eastern Antarctic (Gernandt, 1984). There the containers were collocated for the first German Antarctic research station (Fig. 32). Operations began on 21 April 1976.

In 1976 the changeover crew in Leningrad embarked on the Penjina ice-breaking freighter. Once again a $20^{\prime}$ container, equipped with another A1 sounder, was located on deck. The periodically changing crews operated that sounder during the voyages down to Antarctica and back to Europe (Fig. 33) (Bremer et al., 1980).

\section{Further development of sounding by $\mathrm{A} 1$ and ionosonde}

Beginning in 1967, the focus of ionospheric research of the HHI changed to the area below $100 \mathrm{~km}$ in altitude. In the ionosphere, this is the range of the $\mathrm{D}$ layer and the night- 


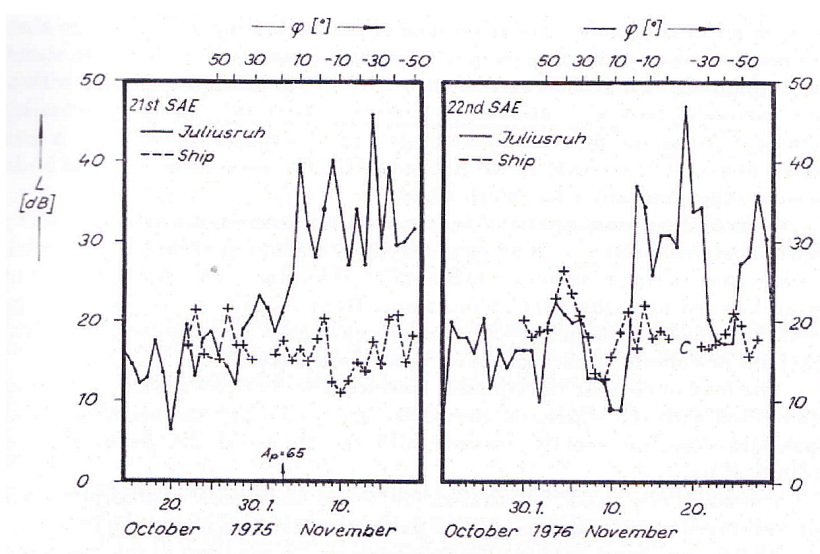

Figure 33. Absorption at $2 \mathrm{MHz}$ and $\cos \chi=0.2(\chi$ : solar zenith angle) onboard ship and at Juliusruh Station; scales at the top: geographic latitudes of the ships.

time E layer. These layers were only detectable via indirect sounding employing the classic sounding methods applied in Juliusruh, using the total reflection from the $\mathrm{F}$ layers and the daytime E layer. In the case of total reflection, the $N_{\mathrm{e}}$ profile below the reflecting layer causes a power attenuation of sounding signals. There was an attempt at continuously recording the signal power of the reflected ionosonde signals, similar to the A1 method, but the technical complexity exceeded the station's capabilities. Another parameter of the ionogram, the $f_{\text {min }}$ (the minimum frequency, where an echo is visible in the ionogram), which is regularly scaled from the ionogram, is suitable for comparative study of absorption in the lower ionosphere. Due to the high efficiency of the Juliusruh ionosonde, the nighttime echo trace already began at $500 \mathrm{kHz}$, the starting frequency of the ionosonde. Therefore, the nighttime values of $f_{\min }$ were unusable. By employing technical changes the starting frequency could be reduced down to $180 \mathrm{kHz}$. Now the nighttime values of $f_{\min }$ were suitable for the calculation of absorption. In addition, echoes of the nighttime E layer from $90 \mathrm{~km}$ now could be temporarily measured. With this starting frequency, Juliusruh had a unique position in the worldwide network of ionosondes, whose starting frequencies mostly were $1 \mathrm{MHz}$.

In the late sixties, analogue and digital semiconductors became available in the GDR. The new electronic components were utilised in Juliusruh to automate the observation service. The station developed its own alarm system (Weiß, 1972) and could substitute the night shift with a stand-by duty from 1970 onwards. The alarm was not only set off by fire or burglar entry, but also by sudden storm commencements (SSC) (Sect. 4) and sudden ionospheric disturbances (SID). In order to generate the alarm trigger for SSC and SID, the magnetometer and the A1 sounder were supplemented by threshold switches.

Damaging by lightning was a common problem after the replacement of electronic tubes and electromagnetic relays by semiconductors. The large antennas are predestined for discharging of atmospheric electricity. So all elevated antennas are grounded by motor-operated switches if a thunderstorm approaches. During the first few years the groundings were triggered manually by operator. Later on, this was done by a threshold switch, connected to a VLF receiver $(500 \mathrm{~Hz})$, watching the level of atmospheric noise. Nevertheless, in a few cases damage occurred due to induction into the interface cables if lightning struck the grounded antennas. This problem could be fixed in the nineties by installing protection in the form of overvoltage fuses on each interface cable that measures $20 \mathrm{~m}$ or more.

In the seventies the development of digital techniques enabled new conceptions for the recording and analysis of data. Unfortunately the laboratories of the HHI in Berlin were outsourced into the new founded Institute of Electronics (later renamed Zentralinstitut für Kosmosforschung) of the AdW. In the HHI remained only a small technical department. So the automation and further development of the observation techniques was a task which the staff of Juliusruh had to perform on their own. For this task the professionally qualified staff members attended courses for hardware developers. Suchlike and other courses were periodically offered by the educational institution of the AdW.

The recording of ionograms still took place photographically at Juliusruh Station during this time. In 1977 a special device for ionogram scaling was constructed. It enabled one to key in and record the scaling code on punch tape. The code consists of a three-digit number among two letters, the socalled ionospheric alphabet. Both the keyboard and the display were made in the small workshop of Juliusruh Station. The display was a mix of glow discharge tubes and lightemitting diodes. Subsequently all of the standard parameters of the Juliusruh ionograms were available machine-readable.

A monthly recurrent task was the preparation of the measurement results for publication in Geohysikalische Beobachtungsergebnisse des HHI, ready to print. This timeconsuming job - including the enumeration of median and quartile values - now could be done by computer.

In 1978 the Juliusruh station got a secondhand computer (GDR-made type D4A) which was used in HHI Kühlungsborn before. It was so large that a special room had to be prepared. This computer room was comprised of two former lodging rooms by removing an interior wall. Again, this job was done by the already mentioned Feierabend-Brigade. The computer programs had to be written in absolute code as the memory was not sufficient for the use of assembler or compiler languages. The development of computer programs as well as the continuous further development of the observation technique rested on the physicists employed in Juliusruh, and they liked this multitasking job. 


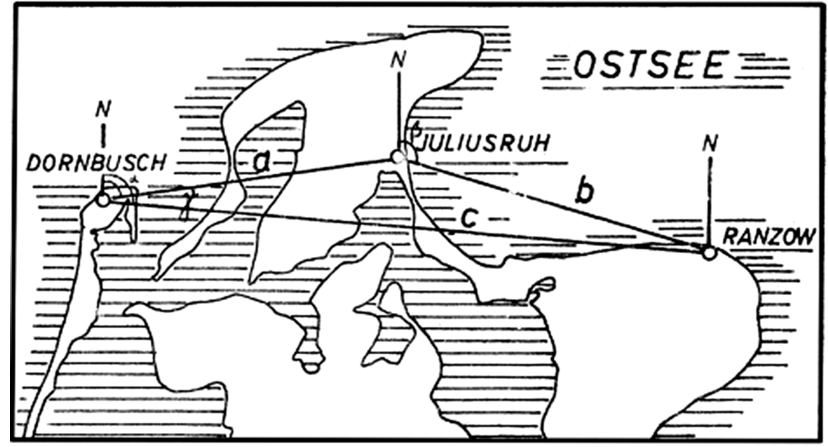

Figure 34. NLC observation network. $\mathrm{a}=16.7 \mathrm{~km}, \mathrm{~b}=17.5 \mathrm{~km}$ and $\mathrm{c}=33.3 \mathrm{~km}$

\section{Other observation methods used temporarily at Juliusruh Station}

Due to the focus of research of the HHI into the atmosphere below $90 \mathrm{~km}$, different methods were experimented with in the station to obtain data from this area.

\subsection{Optometry}

Inside the mesopause, an atmospheric range between 80 and $90 \mathrm{~km}$ above ground, noctilucent clouds (NLC) are sometimes visible. In the period from 1967 until 1972, attempts were made to gauge the structure of NLC and their movement using photogrammetry (Auff'm Ordt, 1973). For this purpose, cameras were positioned in a triangle at these locations (see Fig. 34):

- Juliusruh Station,

- Lighthouse Dornbusch (Hiddensee), and

- Lighthouse Ranzow (Jasmund Peninsula).

The cameras were triggered manually by operators, receiving the trigger command via VLF radio. The measurements aimed at the study of energy flux by waves visible in the NLC. In several cases, jet streams are the presumed origin of the observed waves. An unambiguous relationship could not be verified in all cases.

Another experiment, aimed at measuring waves in the atmosphere, was started on this photogrammetry site: the gauging of wave structures in condensation trails of jets in the stratosphere. Such waves sometimes are visible if the lifetime of the trails is longer than usual, depending on the atmospheric conditions. Those observations principally could be used to record the motions of military jets. This was inadmissible for the HHI civil institution, and therefore the experiment had to be aborted.

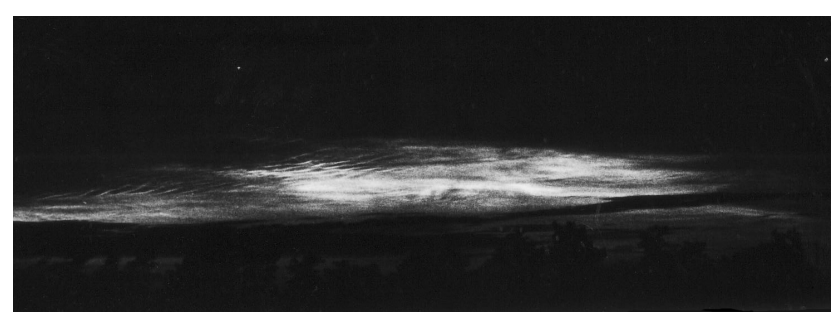

Figure 35. NLC, observed from Juliusruh, 2 July 1967.

\subsection{Low-frequency sounder}

In 1967, a low-frequency sounder was activated in the Kühlungsborn Observatory for research of the altitude range below $100 \mathrm{~km}$. The parameters of the transmitter are the following:

- frequency $314 \mathrm{kHz}$,

- HF power $50 \mathrm{~kW}$,

- pulse-wide $100 \mu$ s, and

- pulse repetition frequency $12.5 \mathrm{~Hz}$.

The signals were received in Juliusruh. For receiving, a delta antenna was built with

- peak height of $52 \mathrm{~m}$,

- base length of $440 \mathrm{~m}$, and

- base height of $6 \mathrm{~m}$.

The receiver was designed in Kühlungsborn using the newest components then available in the GDR like MOS-FETs and mechanical band filters. Both the signal amplitude and the travel-time delay of the sky wave were recorded. The raw synchronisation was done by the $\mathrm{AC}$ powernet and the fine sychronisation by the received ground-wave pulses. The time delay was recorded photographically and the amplitude was recorded by ink recorder on paper. The experiment was carried out from 1968 up to 1971 (Weiß, 1973).

\subsection{Observation of gravity waves by microbarograph array}

In 1982 an array of three microbarographs for the observation of acoustic gravity waves in the troposphere was installed (Neisser, 2009). It was designed and constructed by the department of aeronomy of the HHI, using modified capacitor microphones for measuring air pressure oscillations with periods of $1 \mathrm{~s}$ up to $60 \mathrm{~min}$ (Stangenberg, 1986). Three sensors were located in vats $1.5 \mathrm{~m}$ in the ground, arranged in a triangle of $2.3 \mathrm{~km}$, to acquire the propagation vectors. The devices were located in the station compound and in the nearby villages of Breege and Altenkirchen. 


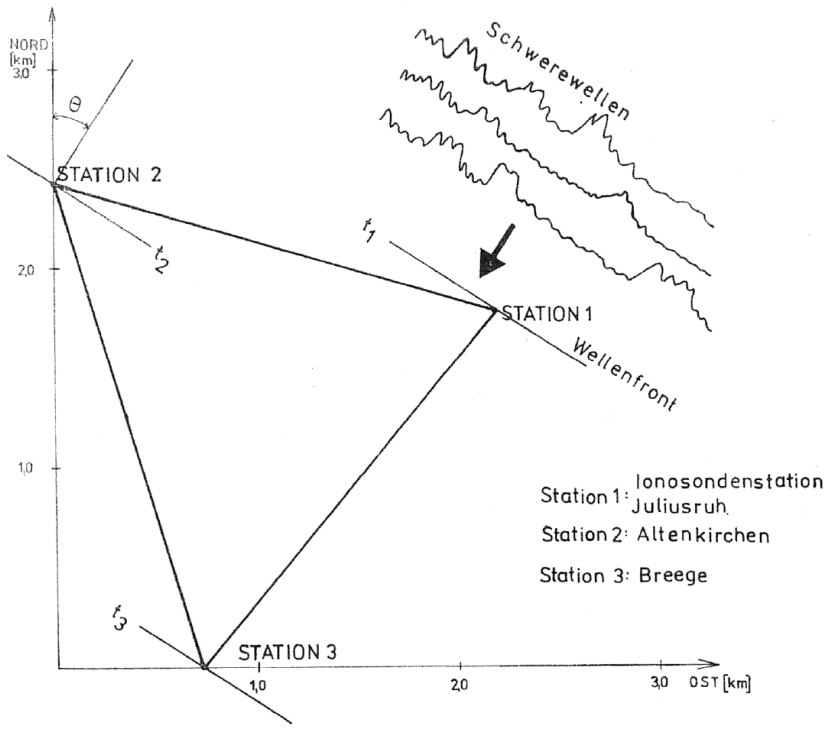

Figure 36. Geometry of the microbarograph network.

Data were transmitted by VLF radio from the remote locations to the station of Juliusruh. The data were captured by a microprocessor system and stored on punch tape. The array was supplemented by meteorological sensors on the $70 \mathrm{~m}$ tower. This system was operated and maintained continuously by the staff of the station until 1991.

In 1990 a cooperation in measuring of gravity waves was started between the HHI and the DLR, Institute of Physics of Atmosphere (Oberpfaffenhofen). In this framework in 19911992, the experiences at the Juliusruh station were the basis for the construction of a copy of the Juliusruh gravity network type in Upper Bavaria at the Lichtenau satellite station (Hauf et al., 1996).

\subsection{Vertical SODAR}

In 1984 a vertical SODAR, called ECHO-1, was designed by the department of aeronomy of the HHI. From 1985 until 1987 this device was tested in Juliusruh (Neisser et al., 1988). The sonic pulses at the frequency of $1.666 \mathrm{kHz}$ were radiated from a horn speaker. The directional effect was achieved by means of a $2 \mathrm{~m}$ parabolic mirror, located on the bottom of a $3.5 \mathrm{~m}$ high funnel cask. The cask was lined by soundabsorbing material to shield it from noise. The echoes, coming back from up to $1600 \mathrm{~m}$, were recorded in the first stage by ink recorder.

At first only temperature inversions were recorded. The system was already prepared with bandpass filters for wind calculation by means of the Doppler shift. This first device was the basic module for the later model: a triple Doppler SODAR. After the end of the test measurements the vertical SODAR in Juliusruh was kept operational until it was destroyed by a lightning strike in 1995 .

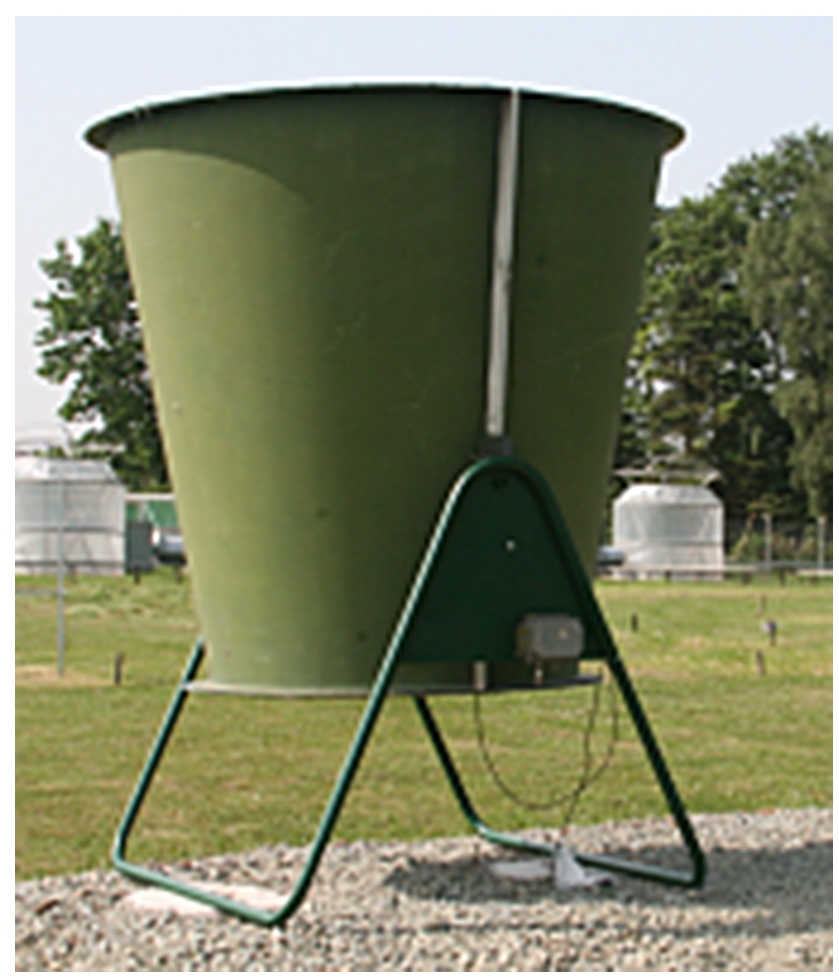

Figure 37. Vertical SODAR ECHO-1 at the Marburg Ground Truth and Profiling Station, Marburg University, LCRS.

\subsection{LIDAR}

In November 1995 the LIDAR labelled HERMES of the French Service d'Aeronomie du CNRS was transferred from Observatoire du Haute Provence to Juliusruh Station. Here it was operated by the staff of Juliusruh until 1997. The LIDAR was directed vertically and used a ND:YAG laser (wavelength $532 \mathrm{~nm}$ ) with $500 \mathrm{~mJ}$ pulse power and $30 \mathrm{~Hz}$ pulse repetition frequency.

The equipment was installed inside a $20^{\prime}$ container and acquired data from 15 up to $95 \mathrm{~km}$ in altitude. The instrument was operational at night. The condition of a cloudless sky is often fulfilled on the Wittow Peninsula, so the LIDAR could operate on average 1 of 3 nights. The aviation authority made a request that the station staff switch off the laser when airplanes fly by in the area. For this purpose, a yacht radar was altered so that the antenna beam was directed $60^{\circ}$ up. The built-in target watch then was used to switch off the laser automatically.

The HERMES LIDAR i.a. was used for observations of NLC. The example in Fig. 38 shows backscattering of NLC over Juliusruh during a field campaign that proceeded from May to August 1995. The weather conditions in this period allowed operations during 40 nights with the LIDAR. In three of them, NLC were observed. The optical NLC observations of the weather station on Cape Arkona, at a distance 


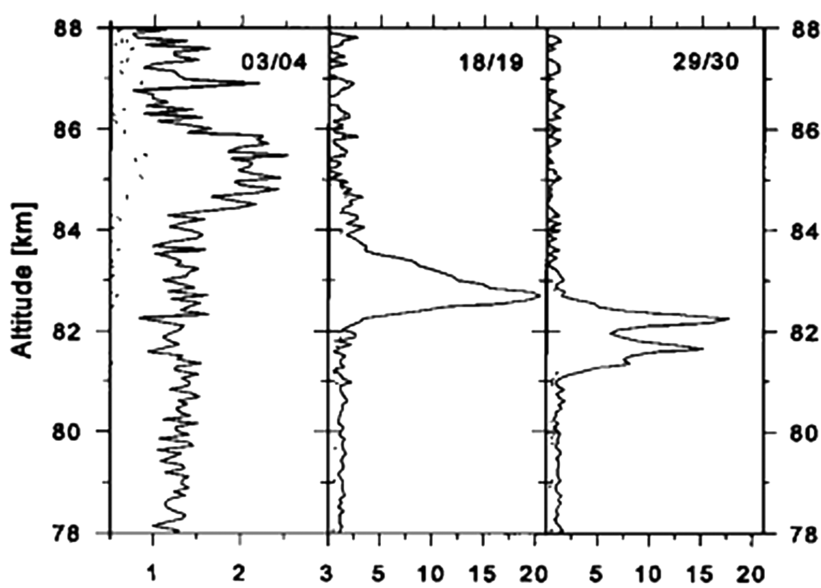

Figure 38. NLC over Juliusruh observed by HERMES-LIDAR, July 1995.

of $10 \mathrm{~km}$, validated the LIDAR results (von Cossart et al., 1996).

Besides the HERMES LIDAR, another LIDAR system, using two dye lasers, in Juliusruh, was established and tested by two colleagues of Kühlungsborn. For this purpose a special annex to the station was built. In 1996 this LIDAR system was moved to Kühlungsborn into the new building of the IAP (Institut für Atmosphärenphysik, Sect. 2). The attached building in Juliusruh was then removed.

\section{MF radar}

Since 1973 at the HHI, a MF radar has been developed for partial reflections from the ionospheric range below $90 \mathrm{~km}$. In contrast to the total reflection in the $\mathrm{E}$ and $\mathrm{F}$ layers, observed by ionosonde and A1 sounders, the MF radar was designed for detection of weak echoes, partially reflected from ionisation irregularities in the altitude above $50 \mathrm{~km}$. The system used frequency modulated continuous waves (FMCW) for transmitting and receiving. The frequency continuously rose during a sounding burst of $0.6 \mathrm{~s}$. The travel time of the signal up and back is calculated from the frequency shift of the transmitter compared to the received signal. With this method a coherent summation is possible, and the signal-tonoise ratio is improved substantially. So the very weak partial reflections can be detected, even though the amplitudes are 50 to $80 \mathrm{~dB}$ below those of the total reflected signals. The MF radar (mean frequency $3.18 \mathrm{MHz}$ ) had a transmitting power of $10 \mathrm{~kW}$.

The transmitting antenna was an array of 16 crossed half-wave dipoles (Franklin Antenna System), clamped on wooden stakes at a height of $11 \mathrm{~m}$ (Fig. 43). Crossed loop antennas clamped on wooden stakes of $12 \mathrm{~m}$ (Fig. 40) served for receiving. The spacing between transmitting and receiving antennas had to be as wide as possible. Those weatherproof loop antennas were formerly used on ships for radio

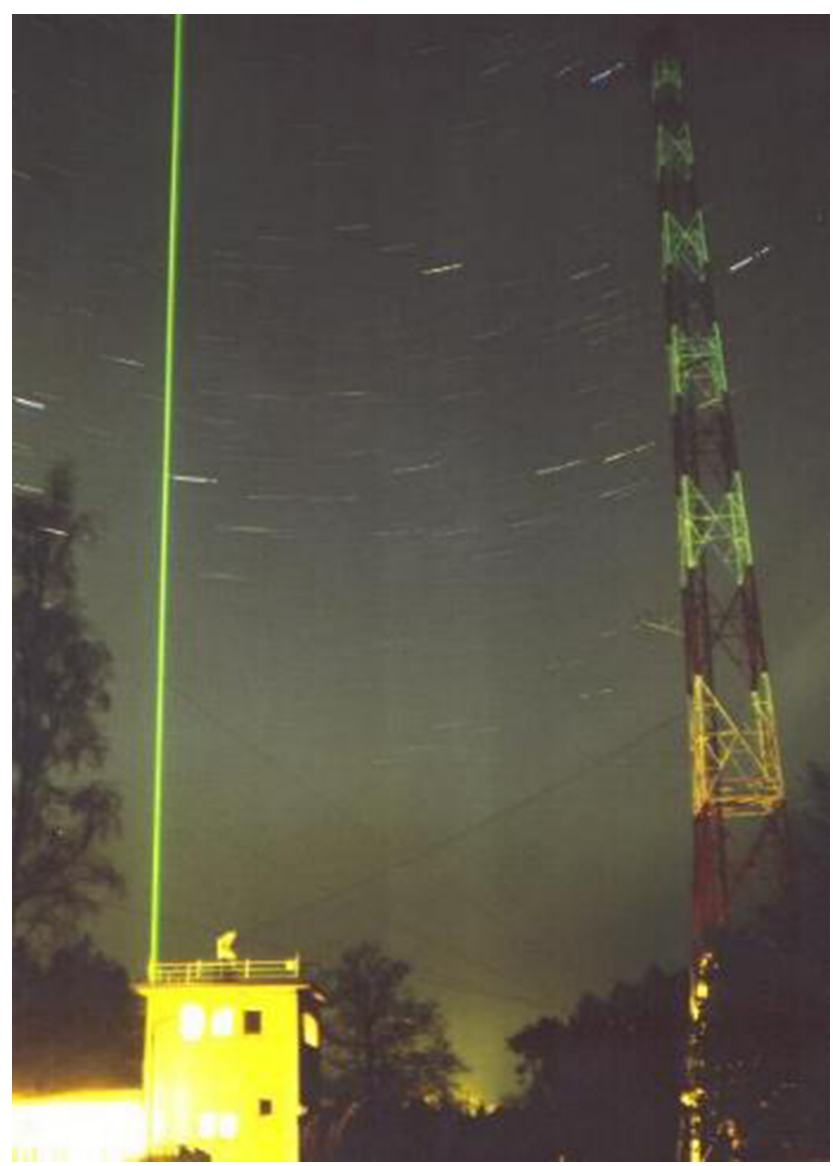

Figure 39. The green beam of HERMES.

orientation. The antennas were purchased from the remainder of the state shipping company of the GDR.

At that time no digital computers were available for realtime Fourier analysis. As an alternative, during the first stage measurements, narrow-band filters for analogue spectrum analysis were used. Due to the complex primary data processing and the problems getting the needed processing equipment (at that time a high-tech embargo against the Eastern bloc was in force), the system could not be put into operation before 8 years of development (Figs. 41 and 42).

The data of MF radar were recorded on magnetic cartridge tape. Later on, at the end of the eighties, a digital Fourier processor at the base of TTL-IC was available for the primary data processing. In 1992 a IBM PC with an i486 CPU was used for this task. Only then did the MF radar produce acceptable results. With this configuration, it operated until 2003.

In 2003 the transmitter and the receiver of the MF radar were substituted by equipment of Australian producer ATRAD, and the system was changed from FMCW to pulse operation.

In 2005 the radar was substituted by a new modular system with active phase array antennas, arranged in the form of a 


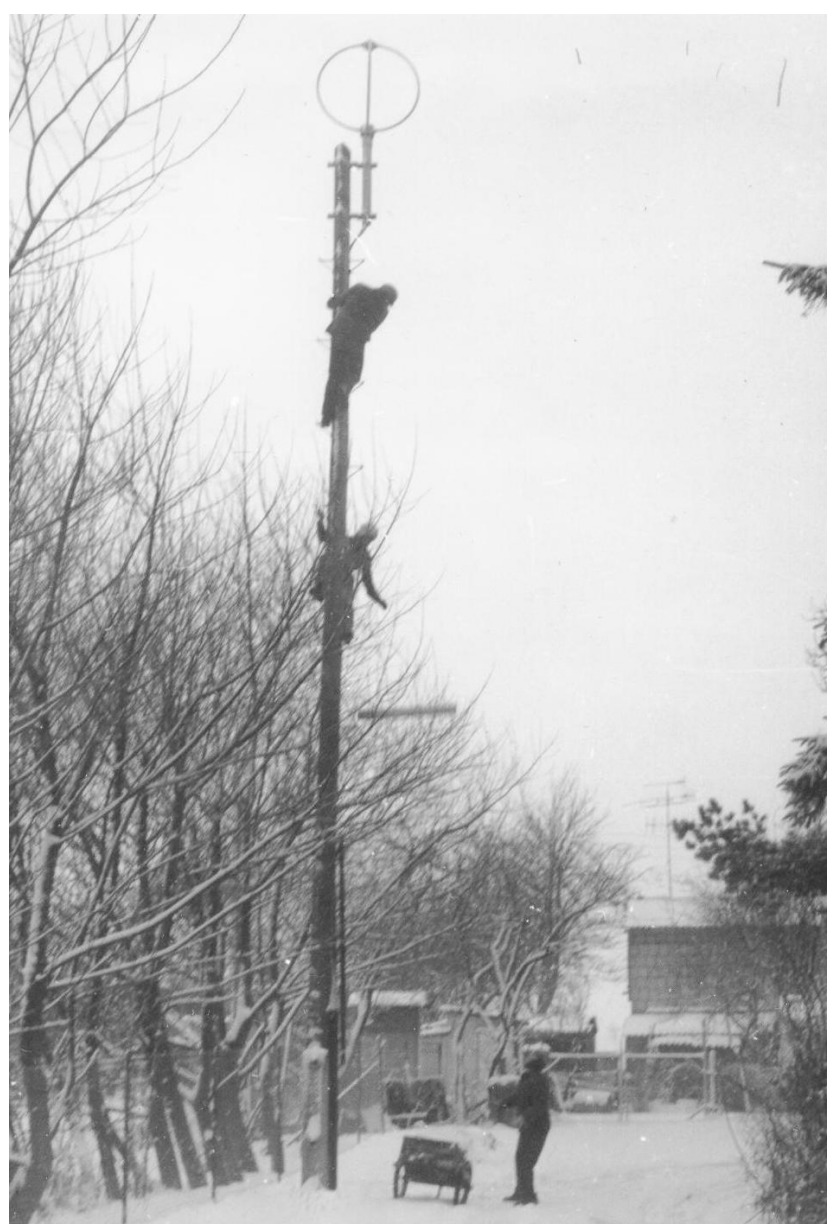

Figure 40. Loop antenna clamped on a wooden stake.

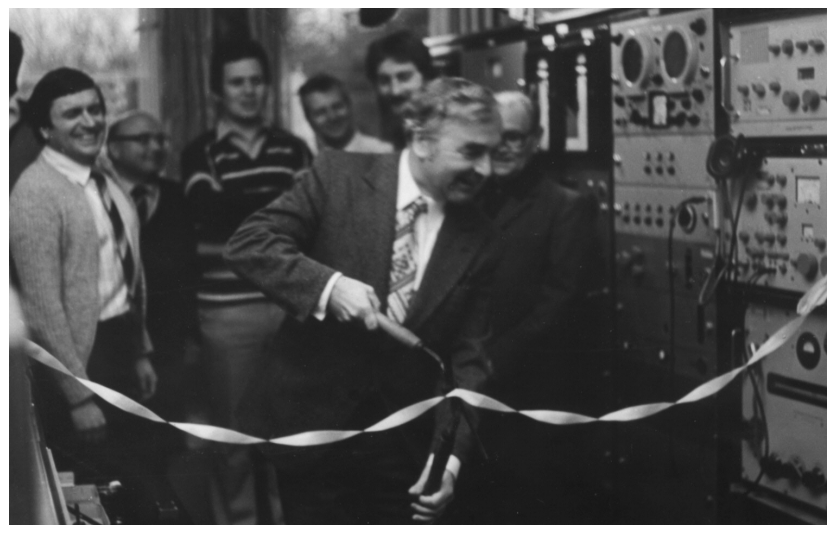

Figure 41. Prof. Dr. Jens Taubenheim sets in operation the MF radar, Juliusruh, 1982.

Mills cross. Since then, the radar has operated with a pulsepeak power of $64 \mathrm{~kW}$ at the old frequency $3.18 \mathrm{MHz}$.

The Mills cross transmitting antenna consists of 13 halfwave dipole crosses (Fig. 44). Each single dipole is connected to a separate transmitter-receiver unit. By means of

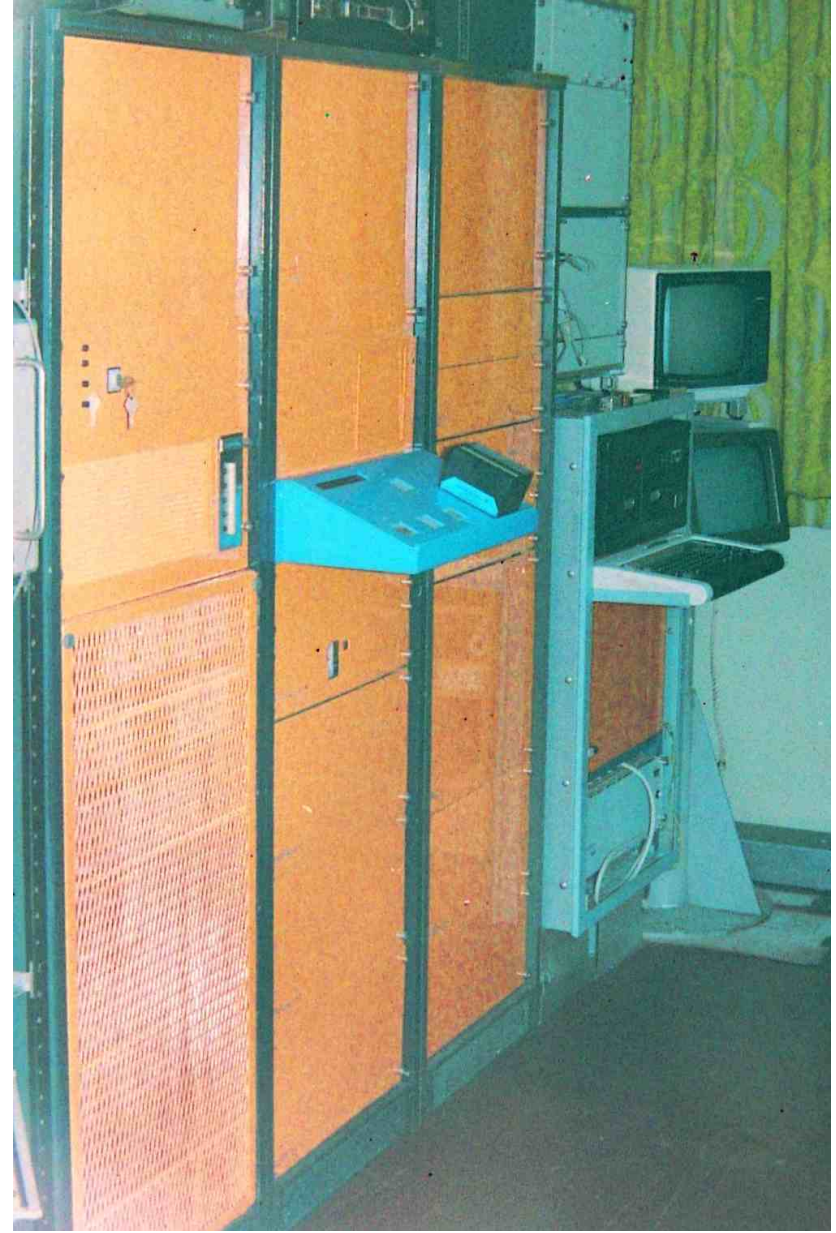

Figure 42. The new MF radar, 1982.

phase-shifted feeding it is possible to operate circular polarisation and to swing the beam. By measuring the Doppler shift as a function of the beam angle (Doppler beam swinging, DBS), the movement of the reflecting plasma between 70 and $95 \mathrm{~km}$ in altitude in steps of $4 \mathrm{~km}$ is computable. Because of the coupling between neutral gas and plasma, the wind in a limited circle around the station is obtained in that altitude range.

\section{SKYMET meteor radar}

Beginning in November 1999, the Juliusruh station operated an all-sky meteor radar called SKYMET. The echoes of ionisation tracks, generated by meteorites burning up in the Earth's atmosphere, are received (Fig. 43, blue) by a five-antenna interferometer (Jones et al., 1998), resulting in a range accuracy of $2 \mathrm{~km}$ and an angular accuracy of better than $2^{\circ}$ in meteor location. Meteor observations have been performed at a frequency of $32.55 \mathrm{MHz}$ with a pulse repetition frequency of $2144 \mathrm{~Hz}$, a pulse width of $13 \mu \mathrm{s}$ (Gaussian shape), and a peak power of $12 \mathrm{~kW}$. The signals are reflected 


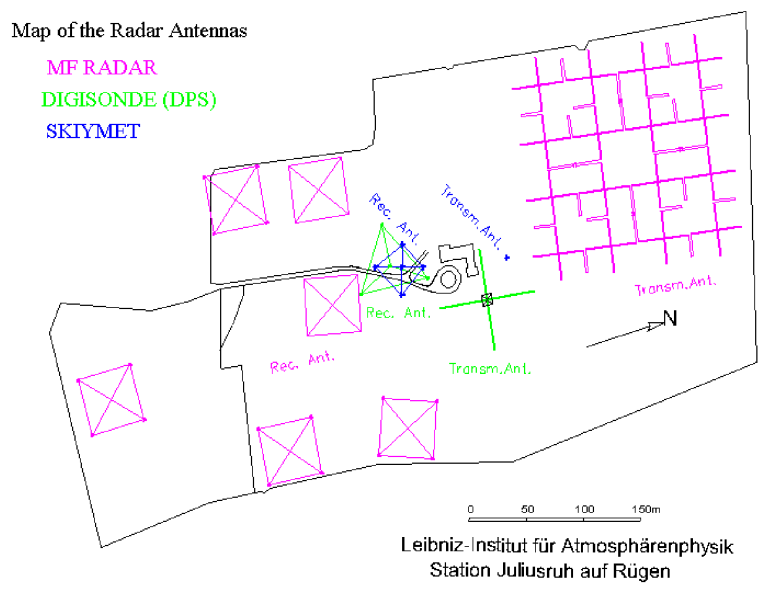

Figure 43. Position of the antennas in Juliusruh Station. The Franklin array (top right) 2004 was substituted by a Mills cross array.

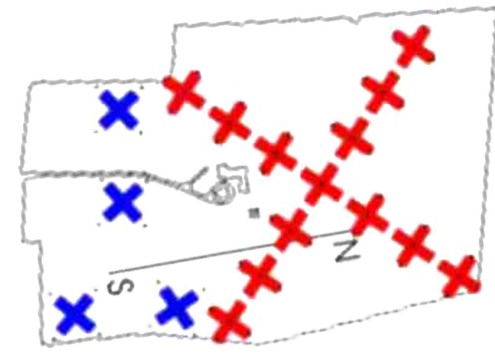

Figure 44. Mills cross MF antenna (red).

by ionisation traces from meteors in the altitude area between 80 and $110 \mathrm{~km}$. The total meteor count rates of unambiguous detections vary throughout the year between 100 and 500 meteors per hour.

With respect to the Doppler shift of the echoes, the wind field in the reflection area can be determined. Moreover, the temperature of the neutral gas is derived from the decay time of the echoes.

In August 2002 the SKYMET was transferred to the Andoya Space Centre in Norway (Singer et al., 2004). There the IAP, together with universities and institutes of eight countries, operates the Arctic Lidar Observatory for Middle Atmosphere Research (ALOMAR). Since 2007 a new SKYMET has operated in Juliusruh at two frequencies: 32.55 and $53.5 \mathrm{MHz}$. The actual number and direction of the meteor echoes is published daily on the internet home page of IAP (Fig. 45).

\section{Ionosonde and the forecast of radio-wave propagation conditions after 1990}

In 1990, the year of Germany's reunification, the closure of the East Berlin Heinrich-Hertz-Institut für Atmosphären-
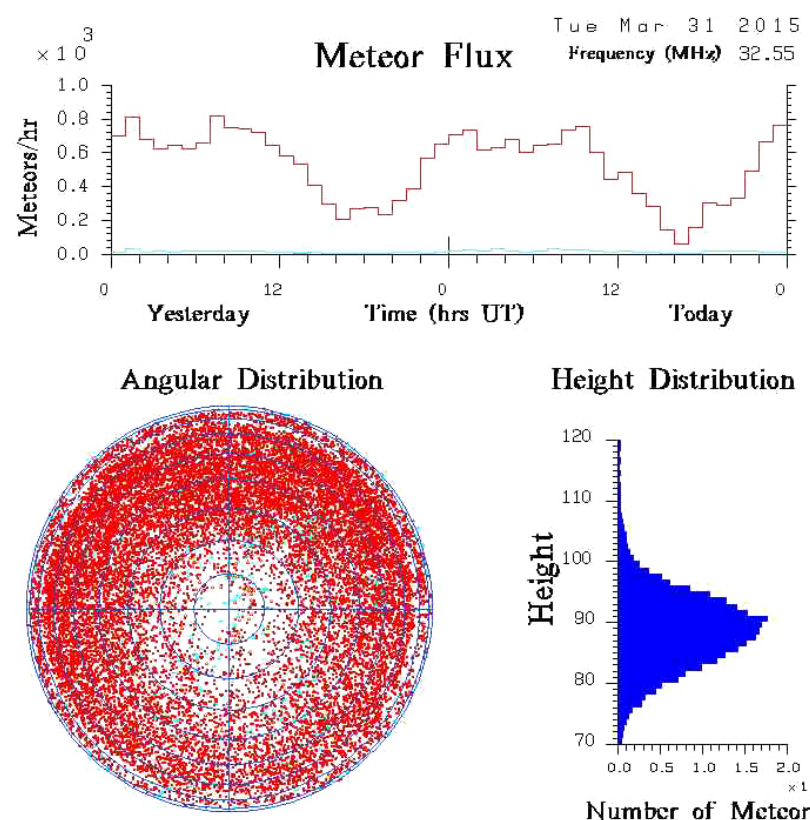

Height Distribution

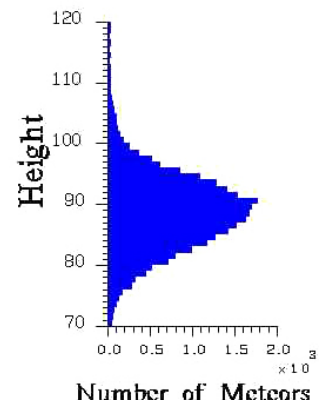

Figure 45. Number, direction and altitude of the meteor echoes, recorded in Juliusruh for the last $48 \mathrm{~h}$ on 31 March 2015.

physik was foreseeable, and the future of all the research themes and observation programmes became uncertain. The continuity of an ionosonde in Juliusruh was soon confirmed. A closure would have left a wide gap in the ionosonde network. The continued existence was strongly recommended by URSI, following a suggestion of Dr. K. Schlegel of the Max Planck Institute for Aeronomy Lindau/Germany.

Besides the continuous operation of the ionsonde, some new projects of environmental monitoring had been contemplated, especially a DOAS station under the auspices of Heidelberg University. DOAS is a method to determine concentrations of trace gases by measuring their specific narrowband absorption structures in the UV and visible spectral region (Platt, 1994). A former watch tower of the East German border patrol seemed well suited for the reflection point of the DOAS path. It was freely visible from the station at a distance of $7 \mathrm{~km}$, and the path would cross the Tromper Wiek bay. Precautionary security of the tower was ensured by the staff of Juliusruh to prevent demolition by the people as a symbol of the bondage in the former GDR. However, the plan was rejected in mid-1992 by the director of the newly established IAP, because of concerns over incompatibility with the provided LIDAR observations.

In March 1990 a digital ionosonde was set into operation, developed and built in Poland under the auspices of the Polish Academy of Sciences, called KOS. The ionosonde was controlled by a PC, and the ionograms were recorded onto a 3.5" magnetic disk. The old ionosonde (type SP-3) was deactivated. The KOS had a transmitting power of $15 \mathrm{~kW}$ and a frequency range of 1.5 to $20 \mathrm{MHz}$, scanned in steps 


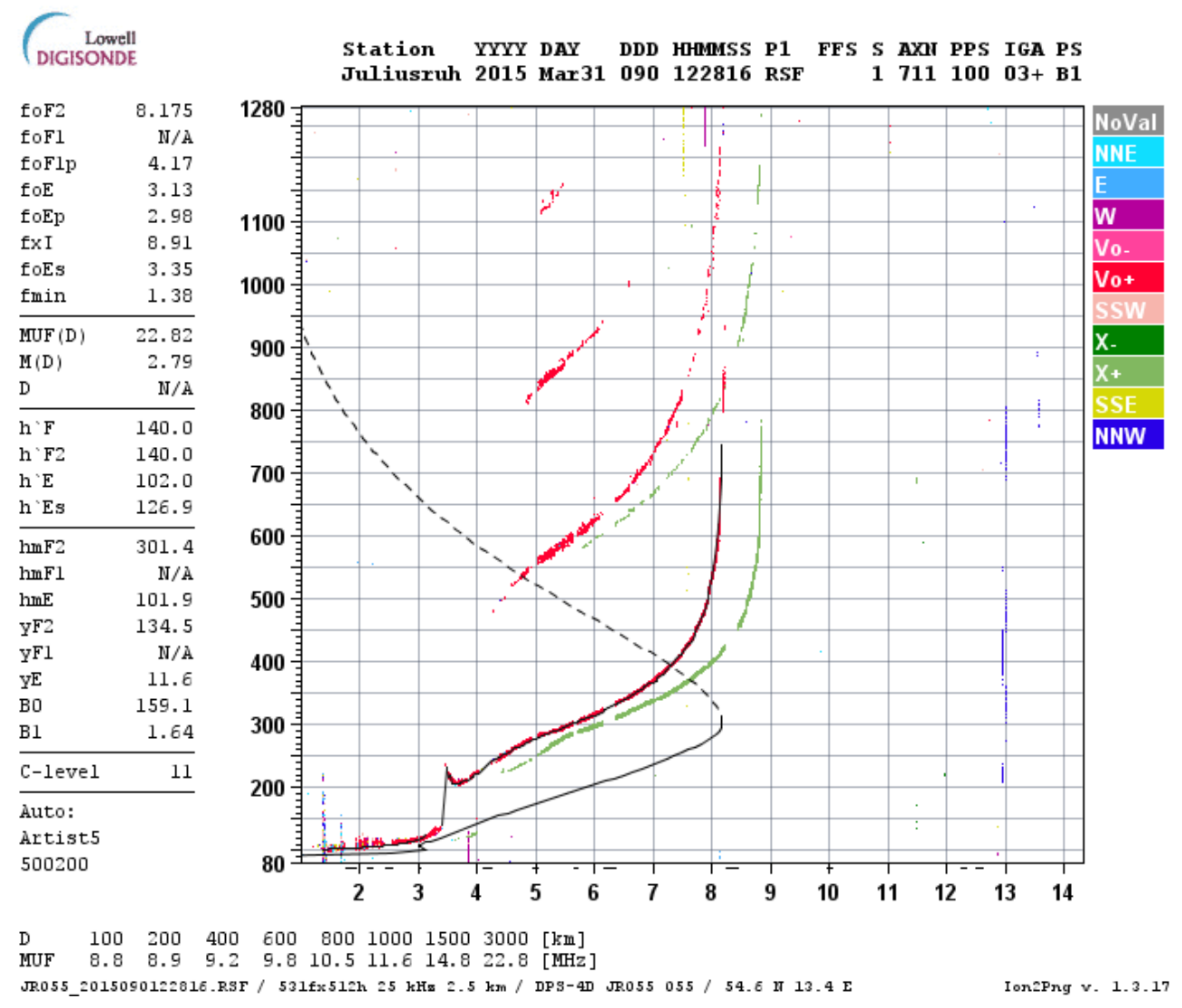

Figure 46. Ionogram by DPS-4D, Juliusruh, 31 March 2015. On the left side some of the automatically scaled characteristics. The black trace is the real-height profile of the plasma frequency, calculated from the ionogram in real time.

of $50 \mathrm{kHz}$. For the scaling of ionograms, a semi-automatic ionogram scaling procedure was developed at Juliusruh, using $\mathrm{C}++$ coding. This software made it possible for the arduous calculation tasks to be made by PC, hitherto carried out by a full-time equivalent.

Together with the end of the GDR state the previous frequency approvals of all the transmitters in Juliusruh became void. With the now applicable regulations the admission was doubtful. This concerned especially the KOS ionosonde, producing a broad noise spectrum. A provisional approval was granted only for a transition period. In 1994 the sounder was moved to the island of Andoya in Norway. There it became a part of ALOMAR, using the location of a former DECCA station with a $140 \mathrm{~m}$ antenna tower.

In West Germany, like in East Germany, existing users of frequency predictions for radio communication still had their requirements. The forecasts were issued by the research institute of the German Bundespost, subsequently named TELEKOM, in Darmstadt. The required database was produced by TELEKOM's own ionosonde, with the transmitter located in Elmshorn near Hamburg and the receiver in Sankt Peter-Ording about $100 \mathrm{~km}$ north of the transmitter. After German reunification, the Juliusruh ionosonde took over the role of data supply, whereas TELEKOM still issued the forecasts. The program system for the forecast calculation of TELEKOM was developed by Dr. Thomas Damboldt.

In 1992 TELEKOM and the IAP contracted the analysis of the Juliusruh ionograms of the last 20 years. The goal was a trustworthy automatically issued forecast of short-term deviations of the F2 layer critical frequency based on real-time geomagnetic field data. The resulting algorithms were developed and successfully tested in Juliusruh until 1994.

TELEKOM ceased the forecast service completely by the end of 1993. Consequently the main customer of the forecasts, the German Bundeswehr, concluded a contract with IAP, valid from 1994. The monthly forecasts were still calculated by Dr. Thomas Damboldt, now as a private subcontractor of IAP, whereas Juliusruh issued the short-term predictions.

In 1992 TELEKOM released their ionosonde to Juliusruh. First only the receiver from Sankt Peter-Ording was transferred; the transmitter remained in Elmshorn. The ionosonde, a CHIRP-SOUNDER produced by BARRY RESEARCH in California, was of current interest for the Juliusruh station, because the KOS ionosonde presumably would not get a permanent frequency approval. The CHIRP-SOUNDER uses 


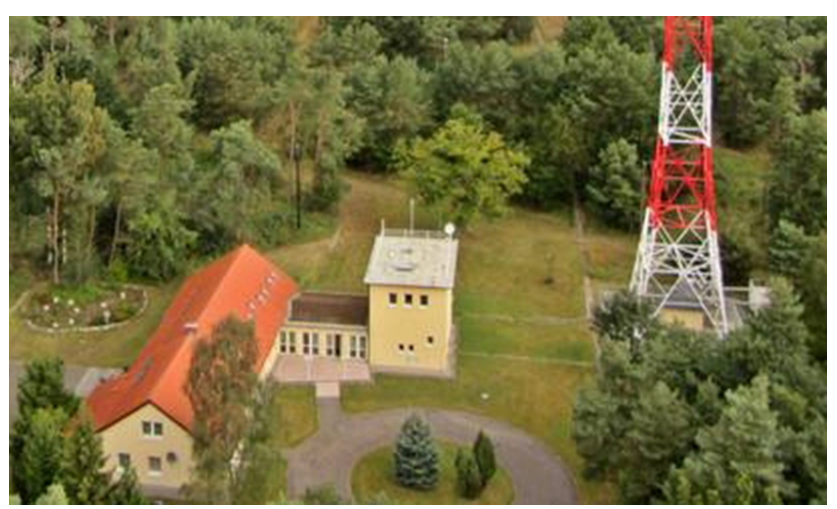

Figure 47. Juliusruh Station today.

the $\mathrm{CW}$ technique (Sect. 10) and had a power of only $5 \mathrm{~W}$, or alternatively $100 \mathrm{~W}$ (switchable). However, it is usable only in bi-static operation: between the locations of the transmitter and receiver, there has to be a distance of several kilometres. The receiver was operated in Juliusruh by test until 1994 . Then TELEKOM also released the transmitter to the IAP.

In 1994 the IAP bought a digital ionosonde system from the Center for Atmospheric Research (UMLCAR) at the University of Massachusetts Lowell. This Digisonde Portable Sounder (DPS-1) was developed by Bodo Reinisch and Mark Haines and has a transmitting power of $150 \mathrm{~W}$ and a transmission bandwidth of $30 \mathrm{kHz}$ (Reinisch et al., 1992). It uses a 16-bit phase-coded pulse and pulse compression and coherent spectral integration to assure a high signal-to-noise ratio. The system progresses continuously, and the UMLCAR holds a bi-annual seminar for Digisonde users, which is faithfully attended by the Juliusruh engineer responsible for the sounding operation.

The DPS has the capability to transmit right- and left-hand circularly polarised waves. For this purpose the transmitting antenna on the $70 \mathrm{~m}$ tower was renovated in early 1995 . The antenna, developed by the American NBS, consists of two crossed rhombuses. As the horizontal extent is only $40 \mathrm{~m}$, no additional masts are needed to stretch the antenna wires. So the outer $52 \mathrm{~m}$ masts were removed, which, together with the $70 \mathrm{~m}$ tower, had characterised the appearance of Juliusruh Station to that point. The DPS uses for receiving four crossed-loop antennas near the ground.

In 1999 the DPS was shipped back to UMLCAR for upgrading from DPS-1 to DPS-4. The upgraded sounder had four receivers, one for each of the received antennas, reducing the acquisition time for angle arrival measurements by a factor of 4. During the 3-month absence of the DPS, the CHIRP-SOUNDER was reactivated in order to continue the required frequency prediction services. Because this sounder has to be operated bi-statically, the transmitter was located in Juliusruh and connected to the transmitting antenna of the DPS, and the receiver in the village of Wiek, in the backyard of the author. The data transfer was achieved by telephone

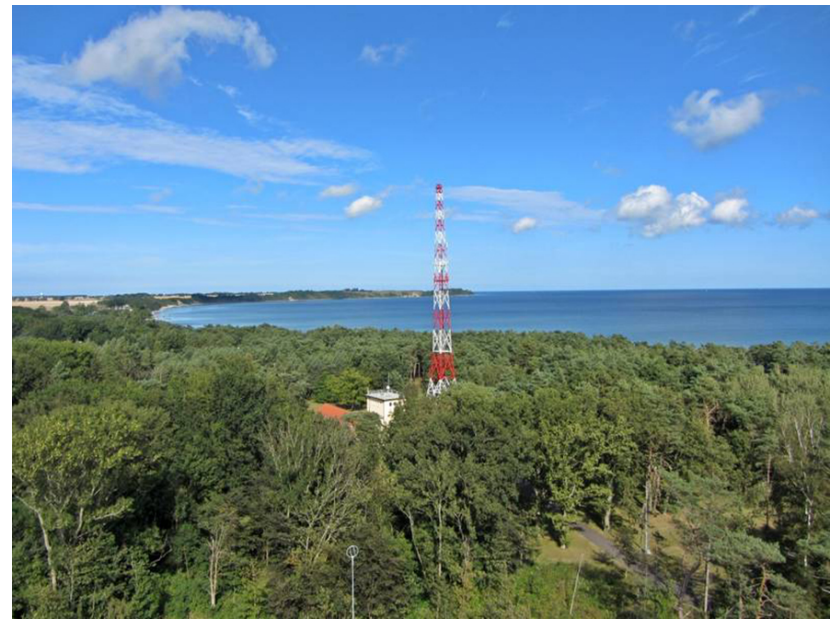

Figure 48. Juliusruh Station today.

modem. The last upgrade of the DPS-4 to a DPS-4D took place in 2011. The DPS-4D runs the significantly improved ARTIST 5 autoscaling system. Precise internal timing and GPS synchronisation (Reinisch et al., 2009) enable by exact synchronisation the receiving of oblique incidence ionograms, transmitted by equally equipped stations in a circle of more than $500 \mathrm{~km}$.

As described above, the history of Juliusruh Station is closely related to the evolution of ionosondes over the last 60 years. The very first ionosonde in Juliusruh only enabled the capture of standard ionospheric characteristics with considerable manual scaling effort after film development. The current system now supplies, in real time,

- amplitude,

- phase,

- Doppler shift,

- incidence angle, and

- polarisation

of the reflected waves, together with the autoscaled ionospheric characteristics and the electron density profile. This enables the monitoring and research of the structure and dynamics of the ionospheric plasma over a large height range. Nevertheless we must not underestimate the importance of the simple old hand-scaled ionospheric characteristics for ionospheric and environmental research. The URSI INAG (Ionosonde Network Advisory Group) working group had initiated and monitored the unified scaling of ionograms in the worldwide ionosonde network at an early stage, making the results comparable. Many of the old data stocks have been digitised and collected in publicly accessible data centres, providing a valuable basis for the discovery of long-term environmental changes. 
Edited by: K. Schlegel

Reviewed by: B. W. Reinisch and J. Taubenheim

\section{References}

Auff'm Ordt, N.: Der Nachweis von Wellen in der Mesopause und deren möglichen Quellen, Inaugural-Dissertation, Universität Rostock, 1973.

Böhm, S., Pöschel, E., and Sommer, M.: Adlershofer Splitter 2, WITEGA e.V., Berlin, 1997.

Breit, G. and Tuve, M. A.: A Radio Method of Estimating the Height of the Conducting Layer, Nature, 116, 357 pp., 1925.

Bremer, J., Gernandt, H., and Lucke, H.: Global Ionospheric Absorption Measurements on Bord Ships, Gerlands Beitr. Geophysik, Leipzig, 89, 1980.

Fanselau, G.: Geomagnetische Feldwaagen, Z. Angew. Geol., 8, Heft 2, 62-64, 1962.

Gauss, C. F.: Allgemeine Theorie des Erdmagnetismus, puplished in: Resultate aus den Beobachtungen des Magnetischen Vereins im Jahre 1838, Weidmannsche Verlagsbuchhandlung, Leipzig, 1839.

Gernandt, H.: Ionosphärische Anomalien in hohen geomagnetischen Breiten, Inaugural-Dissertation, Universität Rostock, 1971.

Gernandt, H.: Erlebnis Antarktis, Transpress VEB Verlag für Verkehrswesen, 229-270, 1984.

Hauf, T., Finke, U., Neisser, J., Bull, G., and Stangenberg, J.-G.: A Ground-Based Network for Atmospheric Pressure Fluctuations, J. Atmos. Ocean. Tech., 13, 1001-1023, 1996.

Jones, W., Webster, A. R., and Hocking, W. K.: An improved interferometer design for use with meteor radars, Radio Sci., 33, 55-65, 1998.

Lange, H. and Tietze, H.: Wetterfrösche für Kurzwellen, Militärverlag, Berlin, 1963.

Neisser, J.: Experimental Investigations of Atmospheric Gravity Waves, Reports on polar and marine research, 588, 73-79, Alfred Wegner Institute, Beremerhaven, 2009.

Neisser, J., Bull, G., Evers, K. Weimann, M., Weiß, E., Keder, J., and Petenko, I. V.: Results of SODAR Investigantion of the Planetary Boundary Layer, Proc. Field Exper. KOPEX-86, Institute of Physics of the Atmosphere of Czech. Acad. Sc., Prague, 109$141,1988$.
Piggott, W. R. and Rawer, K.: URSI Handbook of Ionogram Interpretation and Reduction, Elsevier, Amsterdam, 1961.

Platt, U.: Differential optical absorption spectroscopy (DOAS), Chem. Anal. Series, 127, 27-83, 1994.

Rawer, K.: Die Ionosphäre, Groningen, Noordhoff, 189 pp., 1953.

Rawer, K. and Suchy, K.: Radio Observations of the Ionosphere, in: Handbuch der Physik, V.49/2, Springer, Berlin, 1967.

Reinisch, B. W., Haines, D. M., and Kuklinski, W. S.: The New Portable Digisonde for Vertical and Oblique Sounding, AGARDCP-502, February 1992.

Reinisch, B. W., Galkin, I. A., Khmyrov, A. V., Kozlov, A. V., Bibl, K., Lisysyan, I. A., Cheney, G. P., Huang, X., Kitrosser, D. F., Paznukhov, V. V., Luo, Y., Stelmasch, S., Hamel, R., and Grochmal, R.: New Digisonde for research and minitoring applications, Radio Sci., 44, RS0A24, doi:10.1029/2008RS004115, 2009.

Schlegel, K. and Lühr, H.: Willy Stoffregen - An early pioneer of advanced ionospheric and auroral research, Hist. Geo Space. Sci., 5, 149-154, doi:10.5194/hgss-5-149-2014, 2014.

Singer, W., Bremer, J., Weiß, J., Hocking, W. K., Höffner, J., Donner, M., and Espy, P.: Meteor radar observations at middle and Arctic latitudes, Part 1: mean temperatures, J. Atmos. Sol.-Terr. Phy., 66, 607-616, doi:10.1016/j.jastp.2004.01.012, 2004.

Stangenberg, J.-G.: Anordnung zur Messung geringer atmosphärischer Druckvariationen, DDR Wirtschaftspatent, DD GO1L/236170C, 1986.

Traxler, F. and Schlegel, K.: Hans Mögel, Transradio, and the Mögel Dellinger Effect, Radio Science Bulletin, 351, 53-57, 2014.

Taubenheim, J.: The influence of solar flares on the ionospheric E layer, J. Atmos. Terr. Phys., 11, 14-22, 1957.

Taubenheim, J. and Fürstenberg, F.: Das Heinrich-Hertz-Institut im Internationalen Geophysikalischen Jahr, Wiss. u. Fortschr., 8, 145-149, 1958.

von Cossart, G., Hoffmann, P., von Zahn, U., Keckhut, P., and Hauchecorne, A.: Mid-latitude noctilucent cloud observations by lidar, Geophys. Res. Lett., 23, 2919-2922, doi:10.1029/96GL02768, 1996.

Weiß, E.: Methode und Ergebnisse der ionosphärischen Impulslotung mittels elektromagentischer Wellen auf $314.5 \mathrm{kHz}$ und $185 \mathrm{kHz}$, Inaugural-Dissertation, Universität Rostock, 1973.

Weiß, J.: Überwachung elektronischer Anlagen durch eine Feuerund Havarie-Meldeanlage, Wissenschaftlich-technische Beilage 8/1972 der Zeitschrift "Unser Brandschutz", Staatsverlag der DDR, 1972. 